\title{
Analisis Pengaruh Kredit terhadap Efisiensi Usahatani Padi di Pulau Jawa
}

\author{
Darwis Abubakar $^{1}$, Lukytawati Anggraeni ${ }^{2}$, Anna Fariyanti ${ }^{3}$ \\ ${ }^{1}$ Badan Pusat Statistik Kabupaten Aceh Jaya \\ Jl. Banda Aceh - Meulaboh Km.152 Keutapang, Aceh Jaya 23654, Indonesia \\ ${ }^{2,3}$ Departemen Ilmu Ekonomi, Fakultas Ekonomi dan Manajemen, Institut Pertanian Bogor \\ Jl. Agatis, Kampus IPB Darmaga, Bogor 16680, Indonesia \\ *Korespondensi: darwisab@bps.go.id
}

[diterima: Juli 2019- revisi: Agustus 2019-diterbitkan daring: Desember 2019]

\begin{abstract}
ABSTRAK
Upaya peningkatan produktivitas padi melalui ekstensifikasi semakin sulit dilakukan, sehingga efisiensi produksi menjadi alternatif yang penting. Penelitian ini bertujuan mengestimasi determinan faktor produksi dan tingkat efisiensi usahatani padi serta pengaruh akses kredit, kredit lembaga keuangan formal dan semiformal terhadap inefisiensi teknis usahatani padi. Data cross section dari 9 127 petani di pulau Jawa diperoleh dari Survei Rumah Tangga Usaha Tanaman Padi 2014. Metode analisis menggunakan fungsi produksi stokastik frontier untuk menganalisis produksi dan efisiensi teknis, fungsi biaya dual frontier untuk mengestimasi efisiensi alokatif dan ekonomi serta fungsi inefisiensi teknis untuk mengungkap pengaruh kredit. Hasilnya petani di pulau jawa telah efisien secara teknis namun belum efisien secara alokatif dan ekonomi. Petani yang menerima kredit, kredit dari lembaga keuangan formal dan lembaga semiformal lebih efisien dari petani non-kredit.
\end{abstract}

Kata kunci: akses kredit, efisiensi teknis, lembaga keuangan, stokastik frontier

\section{ABSTRACT}

Efforts to increase rice productivity through extensification are increasingly difficult, so production efficiency becomes an important alternative. This paper aims to estimate the determinants of production factors and level of efficiency of rice farmers and the impact of access to credit, credit of formal and semiformal financial institutions on technical inefficiencies of rice farmers. Cross section data from 9,127 farmers in Java was obtained from the Survey (Rumah Tangga Usaha Tanaman Padi 2014). Analytical method used is stochastic frontier production function to analyze production and technical efficiency, dual frontier cost function to estimate allocative and economic efficiency and technical inefficiency function to reveal the effect of credit. The result is farmers on Java island have been technically efficient but not allocatively and economically efficient yet. Farmers who receive credit, credit from formal financial institutions and semiformal institutions are more efficient than non-credit farmers.

Keywords: Credit Access, Financial Institutions, Frontier Stochastics, Technical Efficiency

JEL classification: G21, O13, Q14 


\section{PENDAHULUAN}

\section{Latar Belakang}

Laju perkembangan produktivitas padi pada tahun 2015 tidak sejalan dengan pertumbuhan penduduk Indonesia. Perkembangan produktivitas padi sebesar $0.2 \%$ sedangkan pertumbuhan penduduk sebesar $1.19 \%$ per tahun (BPS 2013, 2019a). Produktivitas erat kaitannya dengan efisiensi karena memperlihatkan perbandingan besarnya output yang dihasilkan dengan penggunaan input tertentu. Penggunaan input seperti luas lahan, benih, pupuk, pestisida dan tenaga kerja merupakan faktor yang mempengaruhi produktivitas padi.

Upaya peningkatan produktivitas padi melalui ekstensifikasi semakin sulit dilakukan. Hal ini disebabkan oleh keterbatasan dana pemerintah dalam mencetak lahan baru dan konversi lahan pertanian yang sulit dibendung, sehingga upaya peningkatan produksi padi melalui efisiensi menjadi pilihan yang tepat. Efisiensi pada usahatani dipengaruhi oleh beberapa faktor yang berkenaan dengan penggunaan teknologi dan modal.

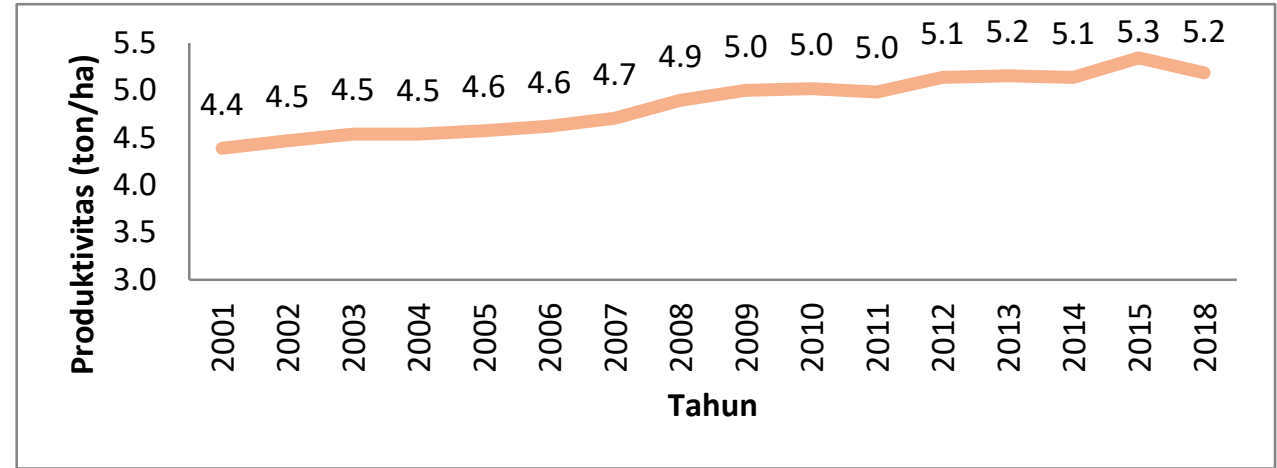

Sumber: BPS (2019a)

Gambar 1. Produktivitas Padi di Indonesia, 2001 - 2018 (ton/ha)

Secara umum produktivitas padi di Indonesia trennya meningkat seperti ditunjukkan Gambar 1, tetapi peningkatannya cenderung melambat. Dalam 18 tahun terakhir penambahan produktivitasnya tidak mencapai satu ton per hektar. Pada tahun 2001, produktivitasnya 4.4 ton per hektar dan naik menjadi 5.3 ton per hektar pada tahun 2015 yang merupakan produktivitas tertinggi, kemudian turun menjadi 5.2 ton per hektar pada tahun 2018 (BPS 2019a).

Peningkatan produktivitas pada sektor tanaman padi hanya dapat dicapai dengan cara menambah jumlah input atau penerapan teknologi baru. Penambahan input atau penerapan teknologi baru akan selalu diikuti dengan penambahan modal, modal yang digunakan dapat bersumber dari modal sendiri atau modal pinjaman (kredit). Modal sangat dibutuhkan dalam rangka pelaksanaan pembangunan ekonomi.

Kredit pertanian dari perbankan merupakan salah satu jalur investasi dari pasar uang untuk meningkatkan pertumbuhan di sektor pertanian.
Pembiayaan kredit secara luas positif berpengaruh terhadap hasil produksi pertanian dan meningkatkan efisiensi melalui pembiayaan investasi modal yang dibutuhkan petani disamping membiayai benih dan pupuk yang juga menguntungkan petani (Qureshi dan Shah 1992). Kredit mikro yang diambil petani secara rata-rata dapat meningkatkan efisiensi teknis usahatani dibandingkan dengan petani yang non-kredit (Tijani dan Aromolaran 2009).

Akses ke layanan perbankan yang berjalan baik dan terorganisir akan memberi peluang yang sama bagi seluruh lapisan masyarakat tanpa terkecuali secara sosial dan ekonomi untuk menghasilkan pendapatan dan mempeluas usahanya (Swamy 2014). Pelayanan keuangan yang menawarkan produk tabungan, pembayaran dan pinjaman belum secara luas diterima oleh masyarakat. Transaksi keuangan masih terpusat di wilayah perkotaan dibanding pedesaan, sedangkan lahan pertanian mayoritas terletak di pedasaan. 
Jumlah kredit yang tersalur menurut OJK (2018) sebagaimana ditunjukkan pada Tabel 1 masih didominasi oleh sektor perdagangan besar dan eceran yaitu sebesar $18.41 \%$ dari total kredit perbankan, sedangkan sektor pertanian, kehutanan dan sarana pertanian menempati urutan ketiga sebesar $6.52 \%$ pada tahun 2017 . Sementara itu hanya $9.4 \%$ petani di Indonesia yang menerima kredit dengan suku bunga (BPS 2015). Hal ini perlu menjadi perhatian kita bersama mengingat sektor pertanian, perburuan dan kehutanan merupakan sektor utama kedua terbesar penyumbang pertumbuhan ekonomi Indonesia sebesar $13.15 \%$ terhadap PDB Tahun 2017 setelah sektor Industri (BPS 2019b).

Tabel 1. Realisasi Kredit Per Sektor Ekonomi dan Sumber Kredit di Indonesia, 2018

\begin{tabular}{rlrrrrrr}
\hline No. & Sektor Ekonomi & $\begin{array}{c}\text { Bank } \\
\text { umum }\end{array}$ & $\begin{array}{c}\text { Bank } \\
\text { Syariah }\end{array}$ & BPR & BPRS & Total & $\begin{array}{c}\text { Persen } \\
(\%)\end{array}$ \\
\hline 1 & $\begin{array}{l}\text { Pertanian, kehutanan } \\
\text { dan sarana pertanian }\end{array}$ & 317.38 & 10.42 & 5.43 & 0.36 & 333.59 & 6.52 \\
2 & Pertambangan & 113.62 & 6.86 & 0.21 & 0.02 & 120.71 & 2.36 \\
3 & Industri Pengolahan & 824.11 & 21.46 & 1.19 & 0.07 & 846.83 & 16.54 \\
4 & Listrik, gas dan air & 146.13 & 11.04 & 0.09 & 0.01 & 157.27 & 3.07 \\
5 & Konstruksi & 258.93 & 22.2 & 2.66 & 0.59 & 284.38 & 5.55 \\
6 & $\begin{array}{l}\text { Perdagangan, restoran } \\
\text { dan hotel }\end{array}$ & 885.45 & 32.84 & 22.70 & 1.76 & 942.76 & 18.41 \\
7 & $\begin{array}{l}\text { Pengangkutan, } \\
\text { pergudangan dan }\end{array}$ & 182.63 & 10.09 & 1.92 & 0.09 & 194.73 & 3.80 \\
komunikasi & Lainnya & 2009.80 & 170.8 & 55.30 & 4.86 & 2240.70 & 43.75 \\
\hline & Jumlah Kredit & 4738.00 & 285.69 & 89.48 & 7.76 & 5120.90 & 100.00 \\
\hline
\end{tabular}

Sumber : OJK 2018

Berdasarkan Tabel 2, pertumbuhan kredit sektor pertanian umumnya mengalami penurunan sepanjang tahun 2011 sampai 2015. Pertumbuhan kredit sektor pertanian paling rendah pada tahun 2014 sebesar 19.84\%. Hal ini sejalan dengan pertumbuhan produktivitas yang mengalami penurunan pada tahun 2014 sebesar -1.92\%. Produktivitas pada tahun berikutnya mengalami peningkatan menjadi 3.9\%. Kredit sektor pertanian diduga erat kaitannya dalam mendorong peningkatan produktivitas dan efisiensi usahatani padi di Indonesia.

Tabel 2. Pertumbuhan Kredit Sektor Pertanian, Perburuan, Kehutanan dan Produktivitas Padi di Indonesia, 2011-2015

\begin{tabular}{ccccc}
\hline \multirow{2}{*}{ Tahun } & \multicolumn{2}{c}{ Kredit Sektor Pertanian } & \multicolumn{2}{c}{ Produktivitas Padi } \\
\cline { 2 - 5 } & $\begin{array}{c}\text { Realisasi } \\
\text { (Trilun) }\end{array}$ & Pertumbuhan $(\boldsymbol{\%})$ & $\begin{array}{c}\text { Nilai } \\
\text { (ton/ha) }\end{array}$ & Pertumbuhan (\%) \\
\hline 2011 & 109.89 & 27.04 & 5.0 & 0 \\
2012 & 142.59 & 29.76 & 5.1 & 2 \\
2013 & 177.24 & 24.3 & 5.2 & 1.96 \\
2014 & 212.40 & 19.84 & 5.1 & -1.92 \\
2015 & 254.96 & 20.04 & 5.3 & 3.92 \\
\hline
\end{tabular}

Sumber: BI (2016)

Kredit adalah salah satu instrumen penting dalam pembangunan ekonomi. Berperan penting dalam investasi, pembentukan modal, proses produksi yang akhirnya dapat memutar roda perekonomian. Usaha-usaha yang ditopang oleh kredit, disalurkan oleh perbankan umum, 
perbankan swasta dan lembaga keuangan mikro. Usahatani masih mengalami kendala dalam mengakses kredit, kendala utama bagi perbankan formal yang tidak memberikan kredit kepada petani disebabkan faktor ketidakpastian dan rentang waktu (time lag) yang tidak memungkinkan petani membayar kredit dengan mekanisme biasa (Wati et al. 2014). Akhirnya petani terjebak pada lembaga informal yang memberi kemudahan bagi petani, tetapi kredit informal ini kerap kali merugikan petani dengan suku bunga yang tinggi (Tenaw dan Islam 2009)

Sebagian besar dari petani tidak mempunyai cukup modal, dan sering terkendala akses pembiayaan karena tidak memiliki aset sebagai agunan (Demirguc-Kunt et al. 2008). Hal ini akan menyebabkan rendahnya tingkat adopsi teknologi, seperti mesin traktor sehingga produktivitas padi menjadi rendah (Nuryartono 2007). Produktivitas tinggi yang diharapkan tidak berhasil terwujud secara maksimum karena proses produksi secara teknis belum efisien, artinya per unit paket input yang dipakai tidak menghasilkan produksi maksimum (Junaedi et al. 2016).

\section{Perumusan Masalah}

Pulau Jawa merupakan sentra lumbung di Indonesia yang memberikan kontribusi besar terhadap produksi beras secara nasional. Tabel 3 menunjukkan Jawa Timur menghasilkan produksi padi sebesar $18.6 \%$ dari total produksi nasional diikuti Jawa Barat (16.9\%) dan Jawa Tengah (16.8\%). Sementara produktivitas padi di Jawa Timur (5.7 ton/ha), Jawa Barat (5.6 ton/ha) dan Jawa Tengah (5.6 ton/ha) berada diatas ratarata nasional (5.2 ton/ha) (BPS 2019a). Produktivitas padi pada wilayah ini cenderung stagnan walaupun perkembangan teknologi alat mesin pertanian (alsintan) yang pesat disebabkan oleh keterbatasan modal petani dalam memanfaatkannya. Salah satu strategi yang dilakukan pemerintah untuk meningkatkan produktivitas adalah adalah pengembangan varietas benih.

Tabel 3. Persentase dan produksi padi tiga provinsi terbesar di Indonesia, 2018

\begin{tabular}{clrc}
\hline No. & Provinsi & Produksi (ton) & Persen (\%) \\
\hline 1 & Jawa Timur & 10596382 & 18.6 \\
2 & Jawa Barat & 9645192 & 16.9 \\
3 & Jawa Tengah & 9609086 & 16.9 \\
4 & Lainnya & 27123982 & 47.6 \\
\hline & Total & 56974642 & 100
\end{tabular}

Petani padi pada umumnya masih berada pada skala usaha kecil dan mikro, sehingga membutuhkan tambahan input seperti modal usaha untuk meningkatkan produktivitas karena usaha petani padi belum efisien secara teknis yang disebabkan penggunaan input yang belum optimal (Wati et al. 2014). Penggunaan faktor produksi yang dioptimalkan harus didukung oleh permodalan yang kuat agar dapat meningkatkan skala usaha petani (Ashari 2009). Hambatan yang berasal dari bank (lembaga keuangan atau ekuitas), ketidaksempurnaan institusi dan usaha sendiri menjadi tantangan utama bagi petani untuk mengakses kredit (Quartey et al. 2017). Tambahan modal berupa kredit diduga berpengaruh terhadap efisiensi usahatani padi, sehingga dapat meningkatkan produktivitas padi.
Usahatani yang berdaya saing dapat diukur dengan tingkat efisiensi teknis, alokatif dan ekonomi. Kemampuan dalam mengombinasikan penggunaan input secara teknis pada tingkat biaya minimum akan berpengaruh terhadap efisiensi suatu produksi. Jika secara teknis penggunaan input digunakan secara tepat, maka akan menghasilkan pada produktivitas yang maksimal. Dikatakan proses produksi secara alokatif efisien ketika proporsi penggunaan input yang hemat biaya ditandai dengan penerimaan marginal produk yang lebih besar dari biaya marginal penggunaan input. Efisiensi ekonomi akan tercapai ketika penggunaan input telah efisien secara teknis dan meminimalkan biaya.

Gambar 2 menunjukkan biaya produksi usahatani padi masih tinggi dari rentang $71 \%$ $73 \%$, menandakan keuntungan yang diperoleh 
petani masih minim. Hal ini juga disebabkan harga jual gabah kering panen (GKP) yang dapat diduga usahatani padi belum efisien secara diterima oleh petani masih rendah, sehingga
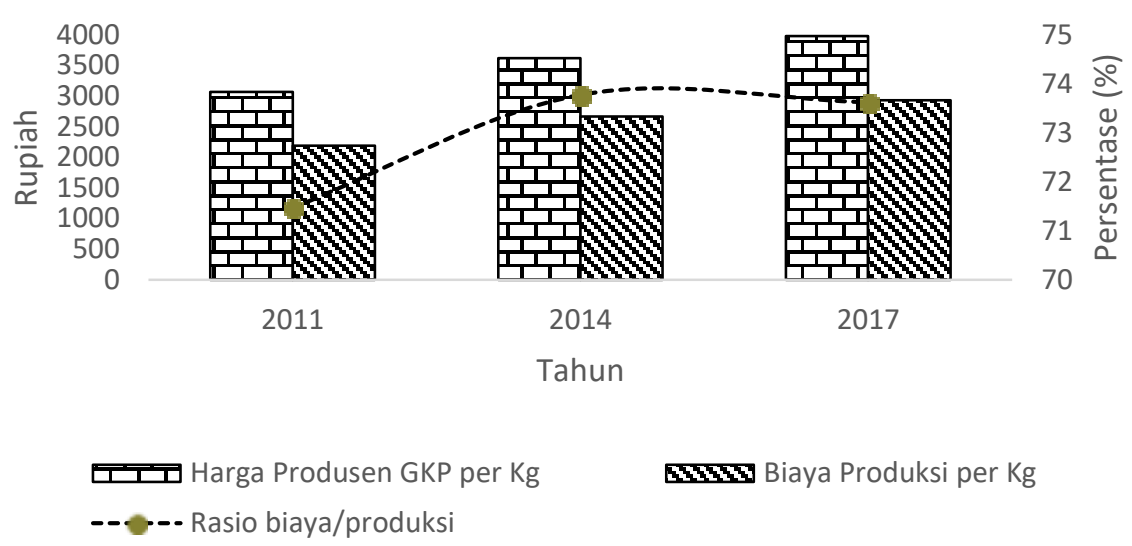

$\mathbf{W 1}$ Biaya Produksi per Kg

Sumber: BPS $(2011,2015,2017)$

Gambar 2. Harga Produsen, Biaya Produksi dan Rasio Biaya/Produksi Usahatani Padi di Indonesia, Tahun 2011, 2014, 2017

\section{TEORI DAN TINJAUAN PUSTAKA}

\section{Fungsi Produksi dan Produksi Frontier}

Fungsi produksi adalah hubungan matematika yang menggambarkan jumlah maksimum barang yang dapat dihasilkan dengan menggunakan kombinasi alternatif antara modal $(K)$ dan tenaga kerja $(L)$ yang diformulasikan dengan bentuk: $q=f(K, L)$, dengan $q$ mewakili keluaran perusahaan untuk satu barang tertentu selama satu periode, $K$ mewakili penggunaan modal selama periode tersebut, $L$ mewakili jam masukan tenaga kerja (Nicholson 2004). Konsep fungsi produksi seringkali disebut hubungan teknis antara kombinasi input-input yang ditranformasi menjadi output. Kondisi di lapangan menunjukkan adanya pilihan penggunaan input yang lebih dari dua. Jika Xi menyimbolkan input-input yang digunakan untuk memproduksi output $\mathrm{Y}$, besar kecilnya $\mathrm{Y}$ bergantung dari besar kecilnya $\mathrm{X}_{1}, \mathrm{X}_{2}, \mathrm{X}_{3}, \ldots, \mathrm{Xi}$ yang digunakan. Secara aljabar hubungan $\mathrm{Y}$ dan $\mathrm{Xi}$ ditulis sebagai berikut: $\mathrm{Y}=\mathrm{f}\left\{\mathrm{X}_{1}, \mathrm{X}_{2}, \mathrm{X}_{3}, \ldots\right.$, $\mathrm{Xi}$ ) dimana: $\mathrm{Y}=$ produksi; $\mathrm{X}_{1}=$ input $\mathrm{X}_{1} ; \mathrm{X}_{2}=$ input $\mathrm{X}_{2} ; \mathrm{X}_{3}=$ input $\mathrm{X}_{3} ; \mathrm{Xi}=$ input $\mathrm{X}$ yang ke-i.

Salah satu fungsi produksi yang banyak dikenal dan digunakan dalam penelitian empiris pada sektor pertanian adalah fungsi produksi Cobb-Douglas. Cobb-Douglas mendasarkan produksi berdasarkan fungsi dari capital/modal dan labor/tenaga kerja. Secara sederhana fungsi produksi Cobb-Douglas dapat dituliskan sebagai berikut: $q=A K^{\alpha} L^{\beta}$, dengan $q$ mewakili output, $L$ mewakili labor , $K$ mewakili capital, sedangkan $A$ adalah pengunaan teknologi, $\alpha$ dan $\beta$ merupakan parameter positif yang ditentukan dari data. Semakin besar nilai A mencerminkan penggunaan teknologi yang semakin maju. Parameter $\alpha$ mengukur persentase kenaikan $q$ akibat kenaikan satu persen $K$ dengan $L$ konstan. Parameter $\beta$ mengukur persentase kenaikan $q$ akibat kenaikan satu persen $L$ dengan $K$ konstan. Elastisitas output terhadap modal dan tenga kerja dicerminkan oleh $\alpha$ dan $\beta$.

Penggambaran fungsi produksi dapat menentukan sifat dari fungsi produksi yang digambarkan secara metematis, dapat menjadi pertimbangan para petani untuk memutuskan berapa besar input produksi yang digunakan dalam menghasilkan output produksi yang optimal. Menurut Coelli et al. (2005) perubahan teknis akibat adanya perbaikan misalnya penggunaan teknologi, akan menggeser kurva produksi ke atas, sehingga dengan penggunaan input (x) yang sama akan menghasilkan output (y) yang lebih besar. Pada Gambar 1 dapat dilihat bahwa seluruh usahatani secara teknis memproduksi output lebih banyak pada setiap tingkat input saat periode $\mathrm{F}_{1}{ }^{\prime}$ dibandingkan dengan periode $\mathrm{F}_{0}$ ', dengan asumsi bahwa input yang digunakan hanya 1 . 


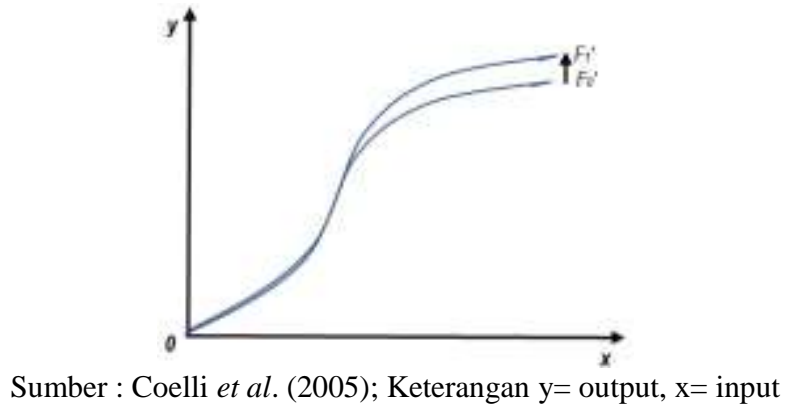

Gambar 3. Fungsi Produksi

Fungsi produksi frontier didefinisikan sebagai hubungan fungsional yang menggambarkan jumlah output maksimum yang dapat dihasilkan dengan menggunakan dua input atau lebih. Secara teoritik suatu fungsi produksi harus memperlihatkan jumlah output yang paling mungkin diproduksi dengan sejumlah input atau kombinasi input tertentu. Namun upaya mempelajari fungsi produksi, pada prakteknya tidak selalu menghasilkan fungsi produksi yang ideal sesuai dengan definisi tersebut. Pendugaan fungsi produksi yang menggunakan metode ordinary least squares (OLS) tentunya tidak mungkin menghasilkan fungsi produksi yang ideal tersebut. Oleh karena itu, upaya-upaya untuk mempelajari efisiensi produksi dengan metode OLS tidak akan memperoleh hasil yang maksimal. Untuk mengukur efisiensi produksi perlu diketahui patokan tingkat produksi maksimum pada tingkat teknologi tertentu dengan pendekatan fungsi produksi frontier (Coelli et al. 2005).

Pengukuran tingkat efisiensi dikategorikan ke dalam pendekatan frontier dan non frontier. Pedekatan frontier diantaranya : (1) deterministic non parametric frontier, (2) deterministic parametric frontier, (3) deterministic statistical frontier, dan (4) stochastic statistical frontier (stochastic frontier). Pendekatan frontier deterministic tidak mempertimbangkan kemungkinan bahwa keragaman usahatani dapat juga dipengaruhi oleh faktor-faktor diluar kontrol pengelola karena model produksi deterministic frontier ini tidak dapat mengurai komponen residual $U i$ untuk menjadi pengaruh efisiensi dan pengaruh eksternal yang tidak tertangkap (random shock), maka nilai inefisiensi teknis cenderung bernilai tinggi karena dipengaruhi sekaligus oleh dua komponen error yang tidak terpisah. Hal lain yang dikemukan Coelli et al. (2005) menjelaskan bahwa di dalam fungsi produksi deterministc frontier tidak ada ukuran yang disertakan untuk menghitung kemungkinan pengaruh lain dari faktor kesalahan dan faktor penganggu yang bisa berada diatas batas produksi. Semua penyimpangan dari batas diasumsikan sebagai hasil dari inefisiensi teknis.

Fungsi produksi stochastic production frontier merupakan perluasan dari model deterministic untuk mengestimasi efek-efek yang tak terduga (stochastic effect) di dalam frontier produksi. Model fungsi produksi stochastic frontier diajukan pertama kali oleh Aigner et al. (1977) dan dikutip dalam Coelli et al. (2005) adalah: $L n$ $Y i=\ln \beta_{0}+\beta_{1} \ln X_{i}+(v i-u i)$.

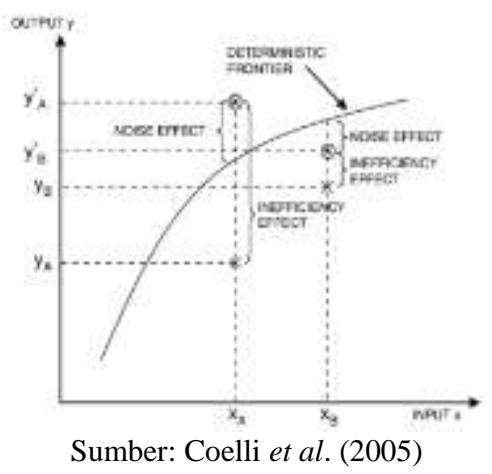

Gambar 4. Fungsi Produksi frontier 
Pendugaan yang tidak bias menggunakan Maximum Likelihood Estimation (MLE) pada model stochastic frontier dilakukan melalui proses dua tahap. Tahap pertama menggunakan metode Ordinary Least Square (OLS) untuk menduga parameter teknologi dan input-input produksi ( $\beta \mathrm{i})$ dan tahap kedua menggunakan metode MLE untuk menduga keseluruhan parameter faktor produksi $(\beta \mathrm{i})$, intersep $(\beta 0)$, dan varians dari kedua komponen kesalahan vi dan ui $\left(\sigma^{2} \mathrm{v}\right.$ dan $\left.\sigma^{2} \mathrm{u}\right)$.

\section{Konsep Efisiensi Teknis, Alokatif dan Ekonomi}

Menurut Farrell (1957) efisiensi perusahaan (usahatani) didefinisikan sebagai produktivitas aktual sebuah usahatani relatif terhadap produktivitas potensial maksimum. Produktivitas potensial maksimum (juga dikenal sebagai frontier dari praktik terbaik) didefinisikan sebagai frontier produksi. Pengukuran efisiensi dilakukan dengan mengukur jarak suatu titik observasi dengan titik frontier-nya. Metodelogi untuk menghitung efisiensi teknis, ekonomis dan alokatif pertama kali diperkenalkannya pada tahun 1957. Dalam metodelogi ini efisiensi ekonomis merupakan penjumlahan antara efisiensi teknis dan alokatif.

Efisiensi teknis (ET) berhubungan dengan kemampuan petani atau perusahaan untuk berproduksi pada kurva frontier isoquan, sedangkan efisiensi alokatif (EA) adalah kemampuan petani atau perusahaan dalam menghasilkan sejumlah output pada kondisi minimisasi rasio biaya output. Berdasarkan kedua definisi tersebut, Farrell (1957) mendefinisikan efisiensi ekonomis (EE) sebagai kemampuan yang dimiliki oleh petani atau perusahaan dalam berproduksi untuk menghasilkan sejumlah output yang telah ditentukan sebelumnya dengan tingkat biaya yang paling minimum pada tingkatan teknologi tertentu (given).

Efisiensi teknis (ET) adalah peningkatan satu output dengan meningkatnya satu input tertentu, dan jika pengurangan satu input membutuhkan peningkatan minimal satu input lain atau berkurangnya minimal satu output. Produsen dikatakan efisien secara teknis jika menghasilkan output yang sama dengan penggunaan input yang lebih sedikit atau dapat menggunakan jumlah input yang sama untuk menghasilkan output lebih banyak. (Koopmans 1951)

Efisiensi alokatif (EA) atau efisiensi yang mengukur tingkat keberhasilan petani dalam usahanya mencapai keuntungan maksimum dengan biaya minimal. Menurut Nicholson (2004) biaya ekonomi adalah biaya kesempatan yang berbeda dengan biaya akuntansi, karena sumber daya terbatas sehingga setiap keputusan dalam sebuah perekonomian untuk memproduksi beberapa barang mengakibatkan tidak diproduksinya barang yang lain. Total biaya biaya yang dikeluarkan perusahaan dapat direpresentasikan dalam:

$$
T C=w L+v K,
$$

dimana $w L$ adalah semua biaya jasa tenaga kerja yang dibayar perusahaan dan $v K$ adalah semua sewa atau harga barang modal yang digunakan. Untuk meminimumkan biaya produksi di tingkat keluaran tertentu, sebuah perusahaan harus memilih titik di kurva $q_{o}$ dimana tingkat substitusi teknis dari $L$ untuk $K$ sama dengan rasio $w / v$. Titik tersebut harus menyamakan tingkat keduanya saat dipertukarkan di pasar. Secara matematis biaya total minimum dapat dihitung dengan turunan fungsi Lagrangian menurut Nicholson (2004):

$$
L=w L+v K+\lambda\left[q_{0}-f(K, L)\right] .
$$

Efisiensi ekonomis (EE) adalah kombinasi antara efisiensi teknis dan efisiensi harga. Pengukuran efisiensi teknis, alokatif dan ekonomis dapat didekati dari dua sisi yaitu pendekatan dari sisi input dan pendekatan dari sisi output. Pengukuran efisiensi teknis dari sisi input merupakan ratio dari input atau biaya batas (frontier) terhadap input atau biaya observasi. Sedangkan pengukuran efisiensi teknis dari sisi output (indeks efisiensi teknis Timmer) merupakan ratio dari output observasi terhadap output frontier. Indeks efisiensi Timmer digunakan sebagai pendekatan untuk mengukur efisiensi teknis di dalam analisis stochastic frontier, sedangkan indeks efisiensi teknis Kopp digunakan untuk mengukur efisiensi teknis yang menggunakan konsep efisiensi Farrell (1957) atau konsep efisiensi teknis dari fungsi biaya dual. 


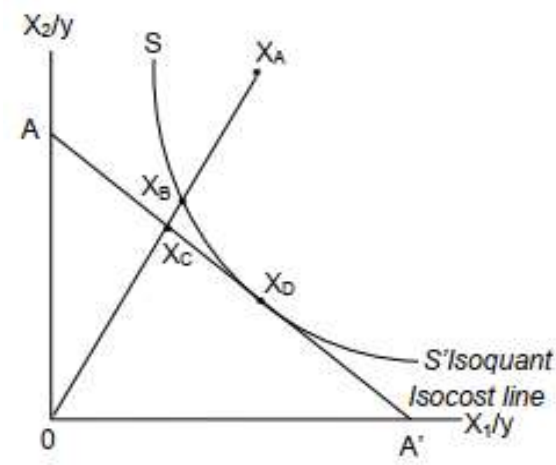

$X_{A}-X_{B}$ : inefisiensi teknis

$X_{B}-X_{C}$ : inefisiensi alokatif

$\mathrm{X}_{\mathrm{A}}-\mathrm{X}_{\mathrm{C}}$ : inefisiensi ekonomis

Sumber: Coelli et al. (2005)

Gambar 5. Efisiensi pada Orientasi Input

Pada Gambar 5, dapat dijelaskan konsep efisiensi pada kondisi pengukuran berorientasi input. Garis axis dan ordinat pada mencerminkan laju penggunaan masing-masing input persatuan output. Sedangkan kurva SS' menggambarkan isoquant unit yang efisien (efficient unit isoquant), yaitu tempat titik-titik yang menunjukkan kombinasi jumlah faktor input produksi minimum yang diperlukan untuk memproduksi satu satuan output. Semua titik yang terletak pada garis SS' dan yang berada diatasnya dapat dicapai, sedangkan semua titik yang terletak antara garis SS' dan titik O tidak dapat dicapai. Dengan demikian garis SS'menggambarkan proses produksi yang secara teknis paling efisien. Titik $X_{A}$ dan $X_{B}$ menggambarkan dua usahatani yang berbeda yang menggunakan kombinasi input dengan proporsi input $\mathrm{X}_{1}$ dan $\mathrm{X}_{2}$ yang sama. Keduanya berada pada garis yang sama dari titik $\mathrm{O}$ untuk memproduksi satu unit Yo. Titik $\mathrm{X}_{\mathrm{A}}$ berada diatas kurva isoquant, sedangkan titik $\mathrm{X}_{\mathrm{B}}$ menunjukkan usahatani yang beroperasi pada kondisi yang secara teknis efisien (karena beroperasi pada kurva isoquant frontier). Titik $\mathrm{X}_{\mathrm{B}}$ mengiplementasikan bahwa usahatani memproduksi sejumlah output yang sama dengan usahatani di titik $\mathrm{X}_{\mathrm{A}}$, tetapi dengan jumlah input yang lebih sedikit. Jadi, rasio $\mathrm{OX}_{\mathrm{B}} / \mathrm{OX}_{\mathrm{A}}$ menunjukkan efisiensi teknis (ET) usahatani, yang menunjukkan proporsi dimana kombinasi input pada $\mathrm{X}_{\mathrm{A}}$ dapat diturunkan, rasio input $\mathrm{X} 1 / \mathrm{X} 2$ konstan, sedangkan output tetap.

Untuk mengetahui tingkat efisiensi alokatif diperlukan informasi harga masing-masing input. Anggap garis $\mathrm{AA}^{\prime}$ mencerminkan harga relatif input X1 dan X2. Gambar 2.3 menunjukkan bahwa titik $X_{B}$ yang terletak pada garis $\mathrm{SS}^{\prime}$ memerlukan sumber daya yang lebih mahal daripada di titik $X_{D}$. Karena setiap kombinasi input yang terletak pada garis yang sejajar dengan garis AA', tetapi lebih jauh dari titik $\mathrm{O}$, mencerminkan kombinasi input yang lebih besar daripada kombinasi input yang terletak pada garis SS. Jarak $\mathrm{X}_{C} \mathrm{X}_{\mathrm{D}}$ menunjukkan adanya efisiensi harga yang masih dapat ditingkatkan. Efisiensi alokatif usahatani $\mathrm{X}_{\mathrm{A}}$ diukur dari rasio $\mathrm{OX}_{\mathrm{C}}$ dengan $\mathrm{OX}_{\mathrm{B}}$. Titik yang efisien secara alokatif dan teknis atau dengan kata lain efisien secara ekonomi berada pada titik $X_{D}$. Efisiensi ekonomi merupakan perkalian antara efisiensi teknis dengan efisiensi alokatif. Untuk efisiensi ekonomi dihitung berdasarkan ratio $\mathrm{OX}_{\mathrm{C}} / \mathrm{OX}_{\mathrm{A}}$.

\section{Pengaruh Kredit terhadap Produksi Padi}

Kredit mikro berpengaruh terhadap pendapatan usahatani melalui pendekatan produksi (production approach), artinya kredit yang diterima oleh usahatani digunakan untuk membeli input dan teknologi baru yang diharapkan dapat menaikkan produksi. Kenaikan produksi, dengan asumsi harga output tetap, akan menaikkan pendapatan petani. Laba usahatani merupakan selisih lebih antara penerimaan usahatani, yang merupakan perkalian antara harga dan kuantitas output yang diproduksi, dengan biaya-biaya yang timbul untuk memproduksi output.

Fungsi produksi menghubungkan input dengan output dan menentukan tingkat output optimum yang bisa diproduksi dengan sejumlah input tertentu, atau sebaliknya, jumlah input 
minimum yang diperlukan untuk memproduksi tingkat output tertentu. Fungsi produksi menggambarkan kombinasi penggunaan input dan tingkat teknologi tertentu yang dipakai suatu unit usaha. Hubungan antara input dan output diformulasikan: $\mathrm{Q}=\mathrm{f}(\mathrm{K}, \mathrm{L}, \mathrm{M}), \mathrm{Q}$ adalah jumlah output dari suatu barang yang dihasilkan selama periode tertentu, $\mathrm{K}$ menunjukkan jumlah modal yang digunakan, $\mathrm{L}$ menunjukkan tenaga kerja yang digunakan, dan $\mathrm{M}$ adalah variabel lain mempengaruhi produksi. Jika dalam proses produksi hanya terdapat dua kombinasi faktor produksi yaitu modal dan tenaga kerja, maka bentuk model hubungan antara output dengan input adalah $\mathrm{Q}=\mathrm{f}(\mathrm{K}, \mathrm{L})$.

Gambar 6 menerangkan kombinasi antara input $\mathrm{K}$ dan $\mathrm{L}$ akan menghasilkan ouput (Q) yang sama pada tingkat teknologi tertentu. Output dari kombinasi tersebut disebut dengan kurva produksi sama (isoquant). Produsen dalam hal ini usahatani dihadapkan pada keterbatasan dana yang dimiliki dalam memilih kombinasi input yang akan memaksimalkan keuntungannya. Keuntungan maksimal akan diperoleh apabila dapat meminimalkan biaya dengan jumlah output yang tetap. Isocost line atau sering juga disebut dengan garis anggaran menggambarkan dana yang dimiliki usahatani yang dapat digunakan untuk membeli faktor produksi yaitu kapital dan labor. Keberhasilan usahatani dalam mengakses kredit menjadikan usahatani memiliki dana tambahan untuk membeli faktor-faktor produksi.

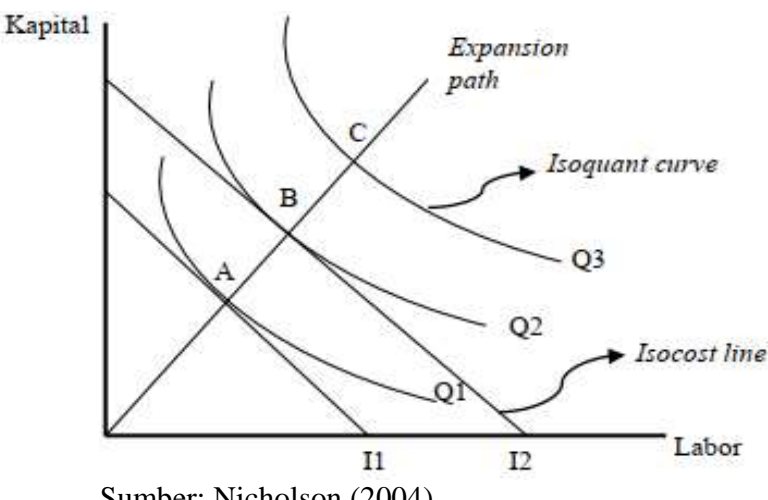

Gambar 6. Hubungan Kurva Isoquant dan Garis Isocost

Usahatani sesuai Gambar 6 yang berhasil mengakses kredit akan memperoleh tambahan dana sehingga garis anggarannya akan bergeser dari I1 menjadi I2. Isoquant curve menggambarkan jumlah produksi/output yang dapat dihasilkan dari kombinasi kapital dan labor. Titik persinggungan antara isocost dan isoquant (titik A, B, dan C) merupakan titik-titik optimal, yang dapat menghasilkan output yang paling maksimal dengan garis anggaran yang ada. Apabila dana yang dimiliki usahatani dicerminkan oleh garis anggaran di I1, maka produksi maksimal yang dapat dihasilkan adalah Q1. Apabila ternyata produksi belum berada pada production frontier, maka masih dimungkinkan untuk menambah produksi dengan menaikkan produktivitasnya. Penambahan capital dan labor dapat menaikkan produksi dari Q1 menjadi Q2 dengan asumsi faktor lain tetap. Usahatani membutuhkan tambahan dana untuk membeli kapital dan labor agar dapat menghasilkan produksi Q2. Tambahan dana yang diperlukan dapat dipenuhi dari modal sendiri atau mengakses kredit dari lembaga keuangan.

Produksi yang dilakukan oleh usahatani dapat bersifat labour intencive (lebih banyak penggunaan tenaga kerja) seperti umumnya pada sistem pertanian di Indonesia, atau bersifat capital intencive dengan lebih banyak menggunakan kapital dan mesin-mesin seperti di negara-negara (Amerika Serikat dan Jepang). Suatu fungsi produksi dapat memberi gambaran tentang produksi yang efisien secara teknis, artinya semua penggunaan input dalam produksi serba minimal atau serba efisien. Peningkatan produksi dapat dilakukan dengan menambah jumlah salah satu input yang digunakan atau menambah beberapa input (lebih dari satu input 
yang digunakan). Total produksi akan bertambah secara perlahan-lahan seiring dengan ditambahnya penggunaan input/faktor produksi dengan asumsi tidak ada perubahan teknologi.

\section{Penelitian Terdahulu}

\section{Faktor-faktor yang memengaruhi produksi} dan efisiensi usahatani padi.

Penelitian mengenai produksi dan efisiensi usahatani telah banyak dilakukan. Faktor-faktor produksi memiliki peranan penting dalam melaksanakan usahatani padi. Usahatani padi merupakan suatu proses mengkombinasikan faktor-faktor produksi berupa lahan, benih, pupuk, pestisida, tenaga kerja dan modal dalam menghasilkan produk dari usahatani padi. Kombinasi penggunaan beberapa faktor input tetap untuk menghasilkan produksi yang baik dan efisien dalam penelitian Junaedi et al. (2017) di Pulau Jawa adalah ; luas lahan, jumlah tenaga kerja, jumlah pupuk dan penggunaan benih nonlokal secara nyata berpengaruh signifikan. Ratarata petani sudah efisien secara teknis sebesar $92 \%$.

Afrin et al. (2017) yang menggunakan konsep produksi stokastik frontier untuk mengukur tingkat efisiensi teknis menyimpulkan bahwa lahan, benih, jumlah tenaga kerja, pupuk dan pestisida berpengaruh nyata terhadap produktivitas padi di Bangladesh dengan tingkat efisiensi teknis rata-rata petani sebesar $86 \%$. Duy (2015) mengukur efisiensi produksi padi petani di Vietnam menunjukkan bahwa faktor luas lahan, benih, pupuk, pestisida dan tenaga kerja luar berpengaruh positif dan nyata terhadap produksi padi sedangkan tenaga kerja keluarga berpengaruh negatif terhadap produksi. Rata-rata petani telah efisien secara teknis sebesar $93 \%$. Sementara Abdallah (2016) meneliti efisiensi produksi jagung di Ghana menemukan bahwa luas lahan, jumlah benih, tenaga kerja, jumlah pupuk berpengaruh positif terhadap produksi jagung sedangkan penggunaan pestisida berpengaruh negatif terhadap produksi. Penggunaan tenaga kerja yang berpengaruh negatif juga ditemukan oleh Chandio et al. (2017) yang meneliti efisiensi produksi padi di Pakistan.

Tinaprilla et al. (2013) yang menganalis efisiensi usahatani padi di Jawa Barat untuk mengetahui faktor apa saja yang memengaruhi produksi dan tingkat efisiensinya. Hasil dari penelitian menunjukkan luas lahan secara signifikan sangat berpengaruh pada taraf $\alpha=5$ persen, dugaan parameter lahan bernilai paling besar (+0.884) dibandingkan dengan variabel lain; tenaga kerja keluarga, bibit, pupuk urea/ZA, pupuk KCL. Sedangkan tenaga kerja luar keluarga, pupuk TSP/SP36, dan pestisida/obatobatan tidak berpengaruh nyata terhadap produksi padi, serta rata-rata petani telah efisien secara teknis sebesar 74\%. Kusnadi et al. (2011) meneliti efisiensi usahatani pada beberapa sentra padi di Indonesia. Hasilnya faktor yang berpengaruh signifikan adalah lahan, bibit, pupuk nitrogen, pupuk phosphor dan tenaga kerja sedangkan pupuk kalium tidak berpengaruh nyata. Petani secara rata-rata telah efisien sebesar $91 \%$.

Sementara itu penelitian Boris et al. (1997) selain efisiensi teknis, dilakukan pengukuran efisiensi alokatif (EA) dan efisiensi ekonomi (EE) untuk mengukur produktivitas. Penelitian ini bertujuan untuk mengetahui efisiensi teknis, alokatif dan ekonomis pada petani kecil. Hasilnya menunjukkan bahwa rata-rata nilai efisiensi teknis, alokatif dan ekonomis adalah sebesar $70 \%$, 44\%, dan 31\%. Penelitian ini menyarankan bahwa banyaknya output yang didapatkan atau penurunan biaya dapat dicapai dengan adanya teknologi. Machmuddin (2016) meneliti efisiensi usahatani padi organik di Jawa Barat yang telah efisien secara teknis dengan rata-rata 0.86 namun belum efisien secara alolakatif (0.44) dan ekonomi (0.36). Tinaprilla et al. (2013) juga melakukan penelitian mengenai tingkat efisiensi teknis, alokatif, dan ekonomi usahatani padi di sentra produksi padi di Indonesia. Walaupun usahatani sudah efisien secara teknis, namun ternyata secara alokatif dan ekonomis belum efisien. Hal ini menunjukkan produksi secara teknis hampir mencapai maksimum akan tetapi belum mencapai keuntungan maksimum. Ini disebabkan petani tidak memiliki informasi yang sempurna tentang harga input dan output dibandingkan informasi teknis. Rendahnya efisiensi ekonomi pada tingkat nasional, selain disebabkan oleh tidak sempurnanya informasi harga, secara alokatif juga belum efisien. 


\section{Faktor kredit yang mempengaruhi efisiensi usahatani padi.}

Penelitian yang menganalisis faktor akses kredit, sumber kredit formal atau informal yang mempengaruhi efisiensi usahatani masih sedikit di Indonesia. Diantaranya Achmad et al. (2012) meneliti pengaruh jumlah akses kredit ke berbagai lembaga keuangan dengan pendekatan metode stokastik frontier menunjukkan akses ke lembaga keuangan, akses penyuluhan dan tingkat pendidikan signifikan berpengaruh negatif terhadap inefisiensi teknis usaha petani Padi di Jawa Barat, Jawa Tengah dan Jawa Timur.

Tinaprilla et al. (2013) menggunakan data Panel Data Nasional (PATANAS) 2013 untuk menganalisis efisiensi teknis usahatani dan faktor yang memengaruhinya dengan menggunakan analisis stokastik frontier. Hasilnya akses ke kredit, usia petani, pendidikan, lahan bukan milik sendiri tidak berpengaruh nyata terhadap efisiensi teknis usaha petani Padi di Jawa Barat sedangkan ukuran keluarga, penggunaan traktor, anggota kelompok tani, musim hujan berpengaruh secara nyata. Junaedi et al. (2016) menganalisis efisiensi teknis usahatani padi sawah dengan menggunakan analisis stokastik frontier menemukan bahwa akses kredit memiliki pengaruh yang nyata terhadap efisiensi usaha petani padi di Pulau Jawa. Variabel lain berpengaruh nyata: pendidikan, penggunaan traktor, mendapat penyuluhan, anggota kelompok tani, dan musim hujan. Sedangkan usia petani, jenis kelamin laki-laki, menerima bantuan, dan lahan bukan milik sendiri berpengaruh negatif terhadap efisiensi.

Chandio et al. (2017) meneliti pengaruh kredit pertanian terhadap produksi padi di Pakistan dengan metode analisis stokastik frontier, hasilnya petani yang menerima kredit berpengaruh signifikan terhadap produksi padi. Sementara Abdallah (2016) meneliti pengaruh akses kredit terhadap efisiensi teknis petani padi di Ghana dengan analisis stokastik frontier menemukan Akses kredit, jenis kelamin, usia, luas tanam, mendapat penyuluhan berpengaruh signifikan dan positif terhadap efisiensi petani jagung. Irigasi juga berpengaruh positif, tetapi tidak signifikan terhadap efisiensi usahatani.
Penelitian terdahulu hanya melihat satu indikator layanan kredit (Akses kredit). Hal baru yang dilakukan oleh Duy (2015) yang meneliti bagaimana hubungan antara petani yang mendapat kredit dari sumber formal terhadap efisiensi usahatani, hasilnya kredit formal (Institusi) berpengaruh secara positif terhadap efisiensi produksi padi. Variabel yang berpengaruh signifikan terhadap efisiensi : pendidikan, jenis kelamin, dan teknologi baru. Sementara Afrin et al. (2017) lebih jauh menganalisis faktor-faktor inklusifitas keuangan yang diduga memengaruhi efisiensi teknis dalam empat indikator yaitu; akses kredit, sumber kredit dari berbagai lembaga keuangan, jumlah kredit yang diambil dan literasi kredit. Hasilnya menunjukkan bahwa keempat indikator ini memengaruhi rata-rata efisiensi teknis petani yang lebih tinggi dibanding petani yang tidak mendapat layanan keuangan yang mendalam.

Berdasarkan ulasan diatas, penelitian ini bertujuan untuk : (1) Menganalisis faktor yang memengaruhi produksi padi di Pulau Jawa, (2) Menganalisis efisiensi teknis, alokatif, dan ekonomi usahatani padi di Pulau Jawa, (3) Menganalisis pengaruh akses kredit, kredit lembaga formal dan semiformal terhadap efisiensi teknis usahatani padi.

\section{METODE}

\section{Jenis dan Sumber Data}

Penelitian tentang pengaruh kredit terhadap efisiensi usahatani padi ini akan memberikan kontribusi dengan melengkapi hasil penelitian yang sudah ada. Kebaruannya ada pada kebaruan data terkini dari tiga provinsi sentra produksi padi, menambah pendekatan efisiensi alokatif dan ekonomi serta mempertimbang sumber pembiayaan kredit.

Penelitian ini menggunakan data Badan Pusat Statistik (BPS) hasil Survei Rumah Tangga Usaha Tanaman Padi tahun 2014 dari tiga provinsi; Jawa Timur, Jawa Barat dan Jawa Tengah. Data meliputi produksi, input produksi dan karakteristik sosial ekonomi petani dengan sampel 9127 rumah tangga usahatani.

\section{Metode Analisis dan Pengolahan Data}

Metode analisis yang digunakan dalam penelitian ini disesuaikan dengan tujuan 
penelitian, yaitu analisis produksi stokastik frontier, biaya dual frontier dan inefisiensi teknis.

\section{Analisis produksi stokastik frontier}

Fungsi produksi stokastik frontier yang digunakan dalam penelitian ini menggunakan model fungsi produksi Cobb Douglas $Y=$ $f(X i, \beta) e^{v-u}$ yang ditransformasi ke dalam bentuk logaritma linier $\ln Y=\ln X, \beta+\left(v_{i}-\right.$ $u_{i}$ ) yang dikutip oleh Coelli et al. (2005) dari model yang diajukan oleh Aigner et al. (1977). Fungsi produksi stokastik frontier ini merupakan perluasan dari model deterministic untuk mengestimasi efek-efek yang tak terduga. Analisis efisiensi teknis (TE) usaha petani padi untuk wilayah ke-j dengan metode Maximum Likelihood Estimation (MLE) sesuai penelitian Duy (2015), Afrin et al. (2017) dan Chandio et al. (2017) :

$$
\begin{aligned}
\operatorname{Ln} Y_{i}= & \beta_{0}+\beta_{1} \ln X_{1 i}+\beta_{2} \ln X_{2 i}+ \\
& \beta_{3} \ln X_{3 i}+\beta_{4} \ln X_{4 i}+\beta_{5} \ln X_{5 i}{ }^{+} \\
& \beta_{6} \ln X_{6 i}+\beta_{7} \ln X_{7 i}+v_{i}-u_{i} \ldots \ldots(1)
\end{aligned}
$$

dengan:

$Y_{i}=$ jumlah produksi padi sawah (ton)

$X_{1 i}=$ luas lahan (ha)

$X_{2 i}=$ jumlah benih $(\mathrm{kg})$

$X_{3 i}=$ jumlah pupuk Urea dan ZA $(\mathrm{kg})$

$X_{4 i}=$ jumlah pupuk TSP $(\mathrm{kg})$

$X_{5 i}=$ jumlah pupuk KCL (kg/ha)

$X_{6 i}=$ jumlah pestisida $(\mathrm{Rp})$

$X_{7 i}=$ jumlah jumlah tenaga kerja $(\mathrm{HOK})$

$\beta_{0}=$ intersep

$\beta_{1}, \beta_{2}, \beta_{3}, \beta_{4}, \beta_{5}, \beta_{6}$ dan $\beta_{7}$ adalah koefisien

dugaan parameter, diharapkan $>0$

$v_{i}-u_{i}=$ error term (vi adalah noise effect, dan ui adalah efek inefisiensi teknis)

$i=$ petani ke-i

Bentuk $\mathrm{v}_{\mathrm{i}}$ adalah galat (error) berupa variasi output yang diakibatkan oleh faktor-faktor eksternal (misal iklim, bencana alam, dan lainnya), sebarannya simetris dan berdistribusi normal $v_{i} \sim \mathrm{N}\left(0, \sigma^{2} v\right)$. Sedangkan $u_{i}$ merefleksikan komponen galat yang sifatnya internal (dapat dikendalikan petani) dan biasanya berkaitan dengan kapabilitas tatakelola petani dalam mengelola usahataninya.
Efek inefisiensi teknis $u_{i}$ selanjutnya dapat mengukur tingkat efisiensi teknis sebagai berikut (Coelli et al. 2005) :

$T E_{i}=\frac{Y_{i}}{f\left(X_{i} ; \beta\right) e^{v_{i}}}=e^{-u_{i}} \quad$ dengan $\mathrm{i}=1,2, \ldots, \mathrm{N}$

dengan nilai efisiensi teknis $0 \leq T E_{i} \leq 1$. Efisiensi teknis adalah kebalikan dari inefisiensi teknis yang nilainya adalah $1-u_{i}$. Efisiensi perusahaan (petani) didefinisikan sebagai produktivitas aktual seorang petani relatif terhadap produktivitas potensial maksimum (Farrel 1957).

\section{Analisis Biaya Dual Frontier}

Analisis efisiensi alokatif dan ekonomi menggunakan pendekatan sisi input. Sebelum mengukur efisiensi alokatif dan ekonomis yang terlebih dahulu dilakukan adalah menurunkan fungsi biaya dual dari fungsi produksi stochastic frontier menurut Coelli et al. (2005) sebagai berikut :

$\ln \left(c_{i}\right)=C\left(y_{i}, r_{i} ; \beta\right)+v_{i}+u_{i} \quad \mathrm{i}=1,2, \ldots . ., \mathrm{n}$

dimana $c_{i}$ adalah biaya produksi petani ke-i; $\mathrm{C}($.) adalah bentuk fungsi produksi biaya CobbDouglas dari $y_{i}$ adalah jumlah produksi padi; $r$ i adalah vektor biaya input; $\beta$ adalah vektor estimasi parameter; dan ui adalah efek inefisiensi biaya yang non-negatif. Berdasarkan fungsi produksi frontier yang ada, fungsi biaya optimum (minimum) ini bisa diperoleh dengan mencari fungsi biaya dual-nya:

$$
C^{*}=\frac{\left[\sum_{i=1}^{7} \beta_{i}\right] Y_{i}^{\frac{1}{\sum_{i=1}^{7} \beta_{i}}}}{\beta_{0}^{\frac{1}{\sum_{i=1}^{7} \beta_{i}}}} \frac{\frac{\beta_{i}}{\prod_{i=1}^{7} r_{i}^{7} \beta_{i=1}^{7}}}{\prod_{j=1}^{7} \beta_{j i} \frac{\beta_{i}}{\sum_{i=1}^{7} \beta_{i}}}
$$

dengan:

$\mathrm{C}^{*}=$ Biaya produksi minimum $(\mathrm{Rp})$

$\mathrm{Yi}=$ Produksi padi $(\mathrm{Rp} / \mathrm{kg})$

$\mathrm{r} 1$ = Biaya sewa lahan (Rp/are)

$\mathrm{r} 2=$ Biaya benih $(\mathrm{Rp} / \mathrm{kg})$

$\mathrm{r} 3$ = Biaya pupuk urea dan ZA $(\mathrm{Rp} / \mathrm{kg})$

$\mathrm{r} 4$ = Biaya pupuk TSP $(\mathrm{Rp} / \mathrm{kg})$

$\mathrm{r} 5$ = Biaya pupuk KCL $(\mathrm{Rp} / \mathrm{kg})$

r6 = Biaya pestisida (Rp/are)

$\mathrm{r} 7=$ Upah tenaga kerja $(\mathrm{Rp} / \mathrm{HOK})$

$\beta_{0}=$ intersep

$\beta_{1}, \beta_{2} \beta_{3}, \beta_{4}, \beta_{5}, \beta_{6}$ dan $\beta_{7}$ adalah koefisien dugaan parameter fungsi biaya frontier 
Persamaan biaya aktual (C) dalam penelitian ini adalah:

$C^{*}=r_{1} X_{1}+r_{2} X_{2}+r_{3} X_{3}+r_{4} X_{4}+r_{5} X_{5}+r_{6} X_{6}+r_{7} X_{7}$

Efisiensi ekonomis (EE) diperoleh dari rasio biaya produksi minimum terhadap biaya total produksi observasi, berada pada kisaran $0 \leq \mathrm{EEi}$ $\leq 1$.

$E E_{i}=\frac{C^{*}}{C}=\frac{E\left(C_{i} \mid \mu_{i}=0, Y_{i}, P_{i}\right)}{E\left(C_{i} \mid \mu_{i}, Y_{i}, P_{i}\right)}=E\left[\frac{\exp \left(u_{i}\right)}{\epsilon_{i}}\right]$

Efisiensi alokatif (AE) per individu usahatani diperoleh dari efisiensi teknis dan ekonomi yang berada di rentang $0 \leq \mathrm{AE} \leq 1$. Sebagaimana rumus berikut ;

$$
A E=\frac{E E}{T E}
$$

\section{Analisis inefisiensi teknis}

Analisisis ini untuk melihat pengaruh inklusi keuangan terhadap efisiensi teknis usahatani padi dengan metode Robust Least Squared menurut penelitian Afrin et al. (2017). Sebelumnya akan dilakukan uji asumsi klasik yang merupakan syarat statistik yang harus dipenuhi seperti uji normalitas, multikolinieritas dan heteroskedastisitas agar memperoleh model terbaik yang memenuhi kriteria BLUE (Best Linear Unbiased Estimator).

Pendugaan parameter inklusi keuangan dilakukan dengan dua model karena adanya persyaratan pada dummy akses kredit, jika mengakses kredit dilanjutkan ke variabel sumber pembiayaan (kredit lembaga keuangan formal atau semiformal). Analisis ini mengikuti penelitian yang dilakukan oleh Afrin et al.(2017):

Model 1 (Akses kredit)

$$
\begin{aligned}
U_{i}= & \delta_{0}+\delta_{1} X_{1 i}+\delta_{2} X_{2 i}+\delta_{3} X_{3 i}+\delta_{4} X_{4 i}+ \\
& \delta_{5} X_{5 i}+\delta_{6} X_{6 i}+\delta_{7} X_{7 i}+\delta_{8} X_{8 i}+ \\
& \delta_{9} X_{9 i}+\delta_{10} X_{10 i}+\delta_{11} X_{11 i}+ \\
& w_{i} \ldots \ldots \ldots \ldots \ldots \ldots \ldots \ldots \ldots \ldots \ldots \ldots \ldots \ldots \ldots \ldots \ldots \ldots \ldots \ldots \ldots \ldots \ldots
\end{aligned}
$$

Ketika akses kredit berpengaruh signifikan, maka akan dilanjutkan ke model 2.

Model 2 (Sumber pembiayaan)

$$
\begin{aligned}
U_{i}= & \delta_{0}+\delta_{1} X_{1 i}+\delta_{2} X_{2 i}+\delta_{3} X_{3 i}+\delta_{4} X_{4 i}+\delta_{5} X_{5 i}+ \\
& \delta_{6} X_{6 i}+\delta_{7} X_{7 i}+\delta_{8} X_{8 i}+\delta_{9} X_{9 i}+\delta_{10} X_{10 i}+ \\
& \delta_{12} X_{12 i}+\delta_{13} X_{13 i}+ \\
& w_{i} \ldots \ldots \ldots \ldots \ldots \ldots \text { (9) }
\end{aligned}
$$

dengan:

$\boldsymbol{U}_{\boldsymbol{i}}=$ Inefisiensi teknis $\left(1-\mathbf{T E}_{\mathbf{i}}\right)$
$X_{1}=$ Umur petani (tahun)

$X_{2}=$ Dummy Jenis kelamin $(1=\mathrm{Lk}, 0=\operatorname{Pr})$

$X_{3}=$ Pendidikan (tahun)

$X_{4}=$ Dummy Ikut Penyuluhan ( $1=$ ya, $0=$ tidak $)$

$X_{5}=$ Dummy Anggota kelompok tani $(1=$ ya, $0=$ tidak)

$X_{6}=$ Dummy Mendapatkan bantuan $(1=$ ya, $0=$ tidak)

$X_{7}=$ Dummy Lahan milik sendiri $(1=$ ya, $0=$ tidak)

$X_{8}=$ Dummy Penggunaan traktor $(1=$ ya, $0=$ tidak)

$X_{9}=$ Dummy Musim tanam (1= hujan, $0=$ kemarau)

$X_{10}=$ Dummy Sawah irigasi $(1=$ ya, $0=$ tidak $)$

$X_{11}=$ Dummy Akses kredit ( $1=$ ya, $0=$ tidak $)$

$X_{12}=$ Dummy Kredit lembaga keuangan formal (1= ya, $0=$ tidak $)$

$X_{13}=$ Dummy Kredit lembaga keuangan semiformal $(1=$ ya, $0=$ tidak $)$

$\boldsymbol{w}_{\boldsymbol{i}}=$ variabel acak

$\delta_{0}=$ intersep

$\delta_{1} . . \delta_{13}=$ parameter dugaan dari variabel inefisiensi teknis

Kredit lembaga keuangan formal meliputi kredit dari perbankan umum, perbankan syariah dan BPR/BPRS. Sedangkan kredit lembaga keuangan semiformal meliputi kredit dari koperasi, baitul mal wat tamwil, leasing dan lembaga keuangan lainnya. Pembagian kelompok lembaga keuangan ini mengikuti sistem perbankan BI sesuai Undang-undang nomor 23 tahun 1999 tentang Bank Indonesia dan Undangundang nomor 82 tahun 2016 tentang strategi nasional keuangan inklusif.

\section{HASIL DAN PEMBAHASAN}

\section{Penggunaan Input dalam Usahatani Padi}

Berdasarkan Tabel 4 terlihat bahwa rata-rata produktivitas padi sawah tertinggi di Jawa Timur sebesar 5.88 ton/hektar, diikuti Jawa Tengah sebesar 4.9 ton/hektar dan Jawa Barat sebesar 4.84 ton/ha. Mayoritas petani di pulau Jawa masih tergolong sebagai petani gurem dengan luas lahan rata-rata kurang dari setengah hektar. Petani di Jawa Barat mengusahakan lahan sawah lebih tinggi dibanding dengan dua provinsi lainnya di Pulau Jawa dengan rata-rata 0.38 ha.

Benih merupakan input yang sangat penting karena pemilihan benih yang unggul dapat menghasilkan produksi yang tinggi. Penggunaan benih per hektar terbanyak ada di Jawa tengah 
sebesar $54.95 \mathrm{~kg}$ dan Jawa Timur sebesar 53.08 kg. Jika dibandingkan dengan rekomendasi dari Badan Litbang Pertanian bahwa benih padi per hektar yang digunakan adalah $20 \mathrm{~kg}$ (BPTP 2016), maka penggunaannya benih padi terlalu berlebihan pada kedua provinsi tersebut. Hanya petani di Jawa Barat yang menggunakan lebih rendah sebesar $41.19 \mathrm{~kg}$ per hektar.

Berdasarkan anjuran Badan Litbang Pertanian penggunaan pupuk urea per hektar paling banyak $240 \mathrm{~kg}$, pupuk TSP/SP36 antara 100-120 kg dan KCL antara 100-150 kg per hektar. Urea adalah pupuk paling penting dalam usahatani. Petani di wilayah Jawa Timur paling banyak menggunakan pupuk urea sebesar $377.38 \mathrm{~kg} / \mathrm{ha}$, jumlah pupuk ini merupakan penggabungan pupuk Urea dan ZA, yang merupakan kelompok pupuk natrium (N). Sedangkan petani di Jawa Barat telah menggunakan urea hampir ideal sebesar 305.84 $\mathrm{kg} / \mathrm{ha}$. Penggunaan pupuk TSP/SP36 di Jawa Timur dan Jawa Tengah telah ideal pada kisaran $120 \mathrm{~kg} / \mathrm{ha}$, sedangkan petani di Jawa Barat menggunakan TSP/SP36 yang lebih banyak yaitu $143.14 \mathrm{~kg} / \mathrm{ha}$. Pupuk KCL yang digunakan di Pulau Jawa masih dibawah anjuran, hanya petani di Jawa Barat yang hampir mendekati penggunaan ideal sebesar $66.65 \mathrm{~kg} / \mathrm{ha}$.

Tabel 4. Rata-rata Penggunaan Input-Output Usahatani dan Provinsi

\begin{tabular}{llrrr}
\hline \multirow{2}{*}{ Variabel } & \multicolumn{1}{c}{ Satuan } & \multicolumn{3}{c}{ Provinsi } \\
\cline { 3 - 5 } & & Jawa Timur & Jawa Barat & Jawa Tengah \\
\hline Produktivitas & $(\mathrm{Ton} / \mathrm{Ha})$ & 5.88 & 4.84 & 4.90 \\
Luas Lahan & $(\mathrm{Ha})$ & 0.33 & 0.38 & 0.28 \\
Benih & $(\mathrm{Kg} / \mathrm{ha})$ & 53.08 & 41.19 & 54.95 \\
Pupuk Urea/ZA & $(\mathrm{Kg} / \mathrm{ha})$ & 377.38 & 305.84 & 348.99 \\
Pupuk TSP/SP36 & $(\mathrm{Kg} / \mathrm{ha})$ & 126.24 & 143.14 & 127.35 \\
Pupuk KCL & $(\mathrm{Kg} / \mathrm{ha})$ & 58.11 & 66.65 & 57.14 \\
Pestisida & $(\mathrm{Rp}(000) / \mathrm{ha})$ & 219.01 & 306.73 & 253.22 \\
Tenaga kerja & $(\mathrm{HOK} / \mathrm{Ha})$ & 78.97 & 88.02 & 78.71 \\
\hline
\end{tabular}

Pestisida atau obat-obatan penyemprotan hama dan penyakit tanaman padi merupakan hal penting. Beragamnya jenis hama, serangan yang intensif dan daya resistensi yang tinggi terhadap obat-obatan mengakibatkan penggunaan pestisida dengan frekuensi yang tinggi. Dari tiga provinsi diatas, pengeluaran pestisida di Jawa Barat adalah terbesar (Rp 306 730/ha), diikuti Jawa Tengah (Rp 253 220/ha) dan Jawa Timur (Rp 219 010/ha).

Proses usahatani tani dengan beragam kegiatan dari pengolahan lahan sampai panen masih banyak menggunakan tenaga manusia sehingga relatif disebut labor intensif. Penggunaan tenaga kerja di Jawa Barat paling besar diantara dua provinsi lainnya sebanyak $88.02 \mathrm{HOK} / \mathrm{ha}$. Sementara Jawa Tengah menggunakan tenaga kerja lebih sedikit sebanyak $78.71 \mathrm{HOK} / \mathrm{ha}$, hal ini menunjukkan bahwa usahatani padi sawah di wilayah tersebut relatif capital intensif.

\section{Analisis Faktor-faktor yang memengaruhi Produksi Padi}

Analisis faktor produksi dalam penelitian ini menggunakan model fungsi stokastik frontier Cobb Douglas untuk menggambarkan hubungan produksi dengan input-inputnya dan melihat faktor-faktor yang memengaruhi produksi padi di lokasi penelitian. Analisis OLS dilakukan terlebih dahulu untuk menguji apakah terdapat pelanggaran asumsi atau tidak. Setelah diuji ternyata terdapat heteroskedastisitas sehingga diregresikan dengan metode Robust $L S$ untuk mengatasinya.

Hasil pendugaan dengan metode Maximum Likelihood Estimation (MLE) diperoleh sigmasquared untuk Jawa Timur, Jawa Barat dan Jawa Tengah adalah berturut-turut $0.09 ; 0.16 ; 0.21$ yang cukup kecil sehingga error terdistribusi secara normal dan variasi yang sama. Nilai gamma terbesar di Jawa Tengah yaitu 0.82 dan berpengaruh nyata taraf $\alpha=1$ persen. Estimasi dengan pendekatan analisis stokastik frontier dikatakan valid karena nilai sigma kuadrat signifikan dan lebih kecil dari nilai gamma, hasil ini sejalan dengan penelitian Fazri et al. (2017) yang meneliti efisiensi teknis pada industri 
menengah dan besar di Indonesia dengan menggunakan analisis stokastik frontier.

Hal lain menunjukkan bahwa $82 \%$ variasi produksi padi diantara petani disebabkan oleh efek efisiensi teknis sementara sisanya sebesar $18 \%$ dipengaruh oleh efek stokastik, sehingga variasi produksi padi di Jawa Tengah lebih banyak dipengaruhi oleh variabel inefisiensi seperti umur petani, pendidikan, alat mesin pertanian, penyuluhan, irigasi dan akses kredit. Nilai log likelihood dengan metode MLE pada semua provinsi lebih besar dari nilai log likelihood dengan metode OLS yang berarti fungsi produksi dengan metode MLE lebih baik dan sesuai dengan kondisi di lapangan. Hasil ini mirip dengan Kusnadi et al. (2011), Achmad et al. (2012) dan Afrin et al. (2017).
Tabel 5 menunjukkan hampir semua parameter hasil estimasi dengan metode MLE pada fungsi produksi padi bernilai positif dan signifikan. Luas lahan berpengaruh signifikan dan positif terhadap produktivitas padi pada taraf satu persen. Pertambahan pada luas tanam akan meningkatkan produksi padi per hektarnya. Pemerintah perlu menjaga lahan produksi pertanian tidak dialihfungsikan yang dapat menyebabkan turunnya luas lahan pertanian. Hasil temuan ini sesuai dengan penelitian Kusnadi et al. (2011), Tinaprilla (2013), Duy (2015); Abdallah (2016); Achmad et al. (2012); Chandio et al. (2017); Afrin et al. (2017) yang menyatakan bahwa luas lahan berpengaruh positif dan nyata terhadap produksi padi.

Tabel 5. Hasil Pendugaan Fungsi Produksi dengan Metode MLE

\begin{tabular}{|c|c|c|c|}
\hline Variabel Input & Jawa Timur & Jawa Barat & Jawa Tengah \\
\hline Intersep & 1.179 *** & $0.795^{* * *}$ & $1.292^{* * * *}$ \\
\hline Luas lahan (ha) & $0.846 * * *$ & $0.794 * * *$ & $0.849 * * *$ \\
\hline Benih $(\mathrm{kg})$ & 0.014 & 0.025 & $0.050 * * *$ \\
\hline PupukUrea(kg) & $0.036^{* * *}$ & $0.058 * * *$ & 0.005 \\
\hline Pupuk TSP (kg) & $0.040 * * *$ & $0.114 * * *$ & $0.105 * * *$ \\
\hline Pupuk KCL (kg) & $0.046 * * *$ & $0.020 * *$ & 0.002 \\
\hline Pestisida (Rp) & $0.012 * * *$ & $0.010^{*}$ & -0.002 \\
\hline T. kerja (Hok) & $-0.012 *$ & $-0.053 * * *$ & $-0.020 *$ \\
\hline Sigma-squared & $0.094 * * *$ & $0.163^{* * *}$ & $0.212 * * *$ \\
\hline Gamma & $0.608 * * *$ & $0.568 * * *$ & $0.822 * * *$ \\
\hline Log likelihood function & 70 & -0.71 & -1.137 \\
\hline LR test & 305 & 168 & 311 \\
\hline $\mathrm{N}$ & 3904 & 2455 & 3768 \\
\hline
\end{tabular}

Penggunaan benih pada Tabel 5 menunjukkan berpengaruh signifikan dan nyata di Jawa Tengah, sedangkan di Jawa Timur tidak nyata disebabkan penggunaan benih hibrida sangat kecil sebesar 4\% dan Jawa Barat sebesar 3\%. Petani yang masih terbiasa dengan penggunaan benih lokal sulit menaikkan hasil produksi padi yang diharapkan.

Penggunaan pupuk urea/za, pupuk TSP dan KCL berpengaruh positif dan signifikan di Jawa Timur dan Jawa Barat, sementara di Jawa Tengah hanya pupuk TSP yang berpengaruh signifikan. Pupuk urea yang berpengaruh tidak nyata ini disebabkan penggunaannya sebesar $269 \mathrm{~kg}$ per hektar melebihi batas maksimal dari anjuran Badan Litbang pertanian (240 kg/ha), sama halnya penggunaan $\mathrm{KCL}$ sebesar $57 \mathrm{~kg}$ yang lebih rendah dari anjuran (100 kg/ha). Hasil ini sejalan dengan penelitian Achmad et al. (2012), Kusnadi et al. (2011) dan Junaidi et al. (2017) yang menyatakan penggunaan pupuk urea, TSP dan KCL berpengaruh signifikan terhadap produksi padi.

Selanjutnya pestisida berpengaruh positif dan signifikan taraf $1 \%$ di Jawa Timur dan berpengaruh positif taraf $10 \%$ di Jawa Barat. Penggunaan Pestisida penting digunakan oleh petani akibat banyaknya serangan hama dan penyakit, rata-rata petani menghabiskan $200-$ 300 ribu rupiah untuk pembelian pestisida. Sejalan dengan yang ditemukan oleh Duy (2015) yang meneliti petani padi di Mekong Vietnam yang menyatakan penggunaan pestisida berpengaruh positif terhadap usahatani padi.

Variabel tenaga kerja sebagaimana di Tabel 5 bernilai negatif disebabkan penggunaan tenaga 
kerja pengolahan lahan yang tinggi (23-30\%) dari total tenaga kerja. Sedangkan mayoritas petani telah menggunakan traktor (74-85\%) di tiga provinsi ini. Penelitian Tinaprilla et al. (2013) Duy (2015) dan Chandio et al. (2017) juga menemukan bahwa penggunaan tenaga kerja dapat menurunkan produksi padi.

\section{Efisiensi Usahatani Padi}

\section{Efisiensi teknis (TE) usahatani padi.}

Distribusi efisiensi teknis yang ditunjukkan Tabel 6, rata-rata ET di Jawa Timur sebesar 0.84, Jawa Barat sebesar 0.79 di Jawa Tengah sebesar 0.71 yang berarti usahatani padi di Pulau Jawa secara teknis telah efisien karena melewati batas efisiensi 0,70 sebagaimana yang dikemukakan Coelli et al. (2005). Para petani telah menggunakan input pada tingkat tertentu dalam mencapai output yang maksimal. Namun masih ada peluang untuk meningkatkan efisiensi teknis mencapai maksimum. Petani yang telah efisien pada nilai di atas 0.70 secara teknis menunjukkan persentase yang telah besar diatas $85 \%$, sehingga mudah untuk menggupayakan peningkatan dengan menggunakan input yang optimal di Jawa Timur dan Jawa Barat. Sedangkan petani di Jawa Tengah yang efisiensi teknisnya berada di atas 0.70 masih sebesar 59\%, masih ada peluang untuk menaikkan efisiensi teknis di provinsi ini dengan usaha yang lebih keras baik oleh petani dan pemerintah (pemberian penyuluhan yang maksimal). Hasil ini sejalan dengan yang ditemukan oleh Duy (2015) di Vietnam bahwa tingkat efisiensi teknis sebesar 0.93; Afrin et al. (2017) di Bangladesh sebesar 0.86; Chandio et al. (2017) di Pakistan sebesar 0.97; Kusnadi et al. (2011) di Indonesia sebesar 0.91 .

Tabel 6. Sebaran Hasil Efisiensi Teknis Usahatani Padi di Pulau Jawa

\begin{tabular}{|c|c|c|c|c|c|c|}
\hline \multirow[b]{2}{*}{ Tingkat Efisiensi } & \multicolumn{2}{|l|}{ Jawa Timur } & \multicolumn{2}{|l|}{ Jawa Barat } & \multicolumn{2}{|c|}{ Jawa Tengah } \\
\hline & Jumlah & Perse & Jumlah & Perse & Jumlah & Perse \\
\hline$<0.30$ & - & - & - & - & - & - \\
\hline $0.30-0.39$ & - & - & - & - & 133 & 3.53 \\
\hline $0.40-0.49$ & - & - & 17 & 0.69 & 296 & 7.86 \\
\hline $0.50-0.59$ & 65 & 1.66 & 135 & 5.50 & 478 & 12.69 \\
\hline $0.60-0.69$ & 288 & 7.38 & 276 & 11.24 & 640 & 16.99 \\
\hline $0.70-0.79$ & 704 & 18.03 & 598 & 24.36 & 962 & 25.53 \\
\hline$>0.80$ & 2847 & 72.93 & 1429 & 58.21 & 1249 & 33.41 \\
\hline Jumlah & 3904 & 100.00 & 2455 & 100.00 & 3768 & 100.00 \\
\hline Rata-rata & 0.8 & & 0.79 & & 0. & \\
\hline Minimum & 0.5 & & 0.43 & & 0 . & \\
\hline Maximum & 0.9 & & 0.94 & & 0 . & \\
\hline
\end{tabular}

Perbedaan tingkat efisiensi teknis yang dicapai petani di lokasi penelitian mengindikasikan tingkat penguasaan dan aplikasi teknologi yang berbeda-beda. Menurut Fadwiwati (2013) perbedaan tingkat penguasaan teknologi dapat disebabkan oleh atribut yang melekat pada diri petani seperti umur, pendidikan dan pengalaman juga dapat disebabkan oleh faktor eksternal seperti kelompok tani dan penyuluhan. Perbedaan dalam aplikasi teknologi yaitu dalam hal penggunaan input produksi disamping disebabkan oleh tingkat penguasaan teknologi, juga disebabkan oleh kemampuan petani dalam penggunaan input produksi.

\section{Efisiensi alokatif (AE) usahatani padi.}

Tabel 7 menunjukkan nilai rata-rata efisiensi alokatif usahatani padi di Jawa Timur sebesar 0.36, Jawa Barat sebesar 0.47 dan Jawa Tengah sebesar 0.48 , artinya usahatani padi belum efisien secara alokatif. Hal ini disebabkan petani belum menggunakan input dengan biaya yang hemat. Sejalan dengan penelitian yang dilakukan Junaedi et al. (2016) rata-rata efisiensi alokatif (EA) 0.57 pada usahatani padi di Indonesia, Machmuddin (2016) menemukan rata-rata 
efisiensi alokatif (EA) 0.49 pada usahatani padi konvensional.

Jika rata-rata petani Jawa Timur dapat mencapai tingkat efisiensi alokatif paling tinggi, maka peluang petani untuk menghemat biaya sebesar (1 - 0.36/0.60) atau 60\%. Sedangkan pada petani yang paling tidak efisien, mereka dapat menghemat biaya sebesar $41.67 \%$ (1 0.25/0.60). Efisiensi alokatif diukur dengan menggunakan dual cost frontier yang secara analitis diturunkan dari fungsi biaya stochastic frontier. Analisis efisiensi alokatif pada penelitian ini diperoleh dari hasil bagi antara efisiensi ekonomi (EE) dengan efisiensi teknis (ET). Belum efisiennya petani secara alokatif diduga karena petani belum dapat meminimalkan biaya usahataninya, salah satu sebabnya petani tidak memiliki informasi yang sempurna mengenai harga input dan output dibandingkan informasi teknis (penggunaan jumlah input). Serta harga pupuk yang biasanya naik saat musim tanam karena kelangkaan atau pupuk subsidi yang terlambat sampai ke petani.

Tabel 7. Sebaran Hasil Efisiensi Alokatif Usahatani Padi di Pulau Jawa

\begin{tabular}{|c|c|c|c|c|c|c|}
\hline \multirow{2}{*}{$\begin{array}{l}\text { Tingkat } \\
\text { Efisiensi }\end{array}$} & \multicolumn{2}{|c|}{ Jawa Timur } & \multicolumn{2}{|c|}{ Jawa Barat } & \multicolumn{2}{|c|}{ Jawa Tengah } \\
\hline & Jumlah & Persen & Jumlah & Persen & Jumlah & Persen \\
\hline$<0.30$ & 101 & 2.59 & 135 & 5.50 & 2 & 0.08 \\
\hline $0.30-0.39$ & 3221 & 82.51 & 417 & 16.99 & 1210 & 32.11 \\
\hline $0.40-0.49$ & 516 & 13.22 & 1110 & 45.21 & 1437 & 38.14 \\
\hline $0.50-0.59$ & 65 & 1.66 & 585 & 23.83 & 531 & 14.09 \\
\hline $0.60-0.69$ & 1 & 0.03 & 146 & 5.95 & 290 & 7.70 \\
\hline $0.70-0.79$ & - & - & 52 & 2.12 & 169 & 4.49 \\
\hline$>0.80$ & - & - & 10 & 0.41 & 128 & 3.40 \\
\hline Jumlah & 3904 & 100.00 & 2455 & 100.00 & 3768 & 100.00 \\
\hline Rata-rata & \multicolumn{2}{|c|}{0.36} & \multicolumn{2}{|c|}{0.47} & \multicolumn{2}{|c|}{0.48} \\
\hline Minimum & \multicolumn{2}{|c|}{0.25} & \multicolumn{2}{|c|}{0.15} & \multicolumn{2}{|c|}{0.27} \\
\hline Maximum & \multicolumn{2}{|c|}{0.60} & \multicolumn{2}{|c|}{0.95} & \multicolumn{2}{|c|}{0.97} \\
\hline
\end{tabular}

\section{Efisiensi ekonomi (EE) usahatani padi}

Efisiensi ekonomi merupakan efek gabungan dari efisiensi teknis dan efisiensi alokatif sehingga usahatani dapat efisien secara ekonomis jika efisiensi teknis dan efisiensi alokatif telah tercapai. Efisiensi ekonomi diperoleh melalui analisis dari sisi input produksi dengan menggunakan harga input dan output dari setiap petani. Biaya input optimun (minimum) diperoleh dari fungsi biaya dual jumlah produksi padi $(\mathrm{Rp} / \mathrm{kg})$, biaya sewa lahan (Rp/are), biaya benih $(\mathrm{Rp} / \mathrm{kg})$, biaya pupuk urea dan ZA (Rp/kg), biaya pupuk TSP/SP36 (Rp/kg), biaya pupuk $\mathrm{KCL}(\mathrm{Rp} / \mathrm{kg}$ ), biaya pestisida (Rp/are) dan upah tenaga kerja $(\mathrm{Rp} / \mathrm{HOK})$ di tingkat petani. Nilai efisiensi ekonomi adalah dari hasil bagi biaya optimum dengan biaya aktual.

Tabel 8 menunjukkan rata-rata efisiensi ekonomi usahatani padi di Jawa Timur sebesar 0.30, Jawa Barat sebesar 0.36 dan Jawa Tengah sebesar 0.32 dengan rentang interval tingkat efisiensi semua provinsi berada di bawah 0.50 yang artinya masih belum efisien secara ekonomi. Rata-rata efisiensi ekonomi paling rendah di Jawa Timur, rendahnya nilai efisiensi ini diakibatkan biaya yang digunakan dalam usahatani masih tinggi (Rp 114 907/ha) yang seharusnya dapat dihemat dengan penggunaan minimal (Rp 34 163/ha). Sedangkan biaya yang dikeluarkan untuk produksi padi per $\mathrm{Kg}$ sebesar Rp 2666 dan hasil yang diterima petani per $\mathrm{Kg}$ sebesar Rp 3 614. Rasio pendapatan yang masih rendah sebesar $28 \%$, sehingga usahatani padi masih sulit mencapai efisiensi secara ekonomi. Harga jual gabah petani juga mempengaruhi nilai efisiensi ekonomi usahatani padi di Pulau Jawa.

Jika rata-rata petani Jawa Timur ingin mencapai tingkat efisiensi ekonomi paling tinggi, maka peluang petani untuk menghemat biaya sebesar (1-0.30/0.34) atau $11.76 \%$. Sedangkan pada petani yang paling tidak efisien, mereka dapat menghemat biaya sebesar $64.7 \%$ (1- 
$0.22 / 0.34)$. Hal ini sejalan dengan penelitian yang dilakukan Junaedi et al. (2016) rata-rata dan efisiensi ekonomi (EE) 0.53 pada usahatani padi sawah di Jawa. Machmuddin (2016) meneliti efisiensi ekonomi padi konvensional di Jawa
Barat belum efisien secara ekonomi dengan ratarata 0.43. Studi Anggraini et al. (2016) juga menemukan bahwa rata-rata efisiensi ekonomi (EE) 0.47 pada usahatani di Lampung.

Tabel 8. Sebaran Hasil Efisiensi Ekonomi Usahatani Padi di Pulau Jawa

\begin{tabular}{|c|c|c|c|c|c|c|}
\hline \multirow{2}{*}{$\begin{array}{l}\text { Tingkat } \\
\text { Efisiensi }\end{array}$} & \multicolumn{2}{|c|}{ Jawa Timur } & \multicolumn{2}{|c|}{ Jawa Barat } & \multicolumn{2}{|c|}{ Jawa Tengah } \\
\hline & Jumlah & Persen & Jumlah & Persen & Jumlah & Persen \\
\hline$<0.30$ & 2231 & 57.15 & 335 & 13.65 & 395 & 10.48 \\
\hline $0.30-0.39$ & 1673 & 42.85 & 1396 & 56.86 & 3373 & 89.52 \\
\hline $0.40-0.49$ & - & - & 724 & 29.49 & - & - \\
\hline $0.50-0.59$ & - & - & - & - & - & - \\
\hline $0.60-0.69$ & - & - & - & - & - & - \\
\hline $0.70-0.79$ & - & - & - & - & - & - \\
\hline$>0.80$ & - & - & - & - & - & - \\
\hline Jumlah & 3904 & 100.00 & 2455 & 100.00 & 3768 & 100.00 \\
\hline Rata-rata & \multicolumn{2}{|c|}{0.30} & \multicolumn{2}{|c|}{0.36} & \multicolumn{2}{|c|}{0.32} \\
\hline Minimum & \multicolumn{2}{|c|}{0.22} & \multicolumn{2}{|c|}{0.14} & \multicolumn{2}{|c|}{0.25} \\
\hline Maximum & \multicolumn{2}{|c|}{0.34} & \multicolumn{2}{|c|}{0.45} & \multicolumn{2}{|c|}{0.38} \\
\hline
\end{tabular}

Belum efisiennya petani secara ekonomi diduga karena petani belum mengalokasikan input secara proporsional yang dapat meminimalkan biaya usahataninya. Efisiensi ekonomi merupakan efek gabungan dari efisiensi teknis dan efisiensi alokatif sehingga usahatani dapat efisien secara ekonomi jika efisiensi teknis dan efisiensi alokatif telah tercapai.

\section{Analisis Faktor-faktor yang memengaruhi Inefisiensi Teknis Usahatani Padi}

Hal pertama yang dilakukan untuk mengetahui pengaruh kredit dengan uji metode Ordinary Least Squares (OLS) ternyata terdapat heteroskedastisitas sehingga untuk mengatasinya dilakukan regesi dengan metode Robust Least Squares. Hasil analisis berdasarkan Tabel 9 pada penelitian ini menunjukkan bahwa seluruh variabel sosial ekonomi berpengaruh beragam terhadap inefisiensi usahatani padi di setiap provinsi. Secara umum umur, tingkat pendidikan, memperoleh penyuluhan, penggunaan traktor, lahan sawah irigasi, akses kredit, kredit lembaga formal dan semiformal berpengaruh negatif terhadap inefisiensi atau diinterpretasikan sebaliknya bahwa faktor-faktor ini memberikan pengaruh positif terhadap tingkat efisiensi usahatani padi sawah. Sementara petani laki-laki, anggota kelompok tani, lahan milik sendiri, dan musim tanam secara umum berpengaruh positif terhadap inefisiensi, artinya faktor-faktor ini justru menyebabkan usahatani padi sawah menjadi tidak efisien.

Umur petani berpengaruh negatif dan signifikan terhadap inefisiensi usahatani padi sawah di Jawa Timur. Umur petani ini adalah proxy dari pengalaman petani. Semakin tua umur petani menunjukkan tingkat pengalaman yang semakin matang dalam bertani padi sawah sehingga lebih efisien, petani di Jawa Timur didominasi oleh petani yang berumur 50 tahun keatas sebesar $60.6 \%$. Sedangkan petani di Jawa Barat bertanda positif karena petani usia muda dibawah 50 tahun sebesar $41.3 \%$ lebih besar dari petani muda di Jawa Timur. Hasil mengenai pengaruh umur yang lebih tua berpengaruh negatif sejalan dengan penelitian Duy (2015), Abdallah (2016) dan Anggraini et al. (2016). Sebaliknya pengaruh umur petani bertanda positif terhadap inefisiensi usahatani padi sawah, artinya semakin berumur petani maka akan menurun tingkat efisiensi sejalan dengan yang diteliti Kusnadi et al. (2011), Tinaprilla et al. (2013), Junaedi et al. (2017) dan Afrin et al. (2017) yang menemukan umur berpengaruh positif terhadap inefisiensi usahatani padi. 
Tabel 9 menunjukkan perbedaan inefisiensi teknis antara petani laki-laki dan perempuan sebesar 0.016 di Jawa Timur. Petani laki-laki berpengaruh positif dan signifikan terhadap inefsiensi usahatani padi sawah di Jawa Timur dan Jawa Tengah, artinya petani perempuan relatif lebih efisien dibandingkan petani laki-laki. Hal ini disebabkan persentase petani perempuan yang kecil (11\%) disamping faktor tingkat ketekunan dan ketelitian dalam berusahatani sehingga waktu tanam yang tepat dan penggunaan pupuk dan pestisida yang sesuai anjuran dibanding petani laki-laki. Sejalan dengan hasil yang ditunjukkan oleh Junaedi et al. (2017) mengestimasi faktor-faktor yang menentukan efisiensi dan kesenjangan teknologi usahatani padi di Pulau Jawa yang hasilnya menunjukkan bahwa petani perempuan berpengaruh positif terhadap efisiensi teknis.

Tabel 9. Hasil Pendugaan Fungsi Inefisiensi Teknis dengan Robust LS di Pulau Jawa

\begin{tabular}{|c|c|c|c|c|c|}
\hline \multirow[b]{2}{*}{ Variabel Inefisiensi } & \multicolumn{2}{|c|}{ Jawa Timur } & \multicolumn{2}{|c|}{ Jawa Barat } & \multirow{2}{*}{$\begin{array}{c}\text { Jawa Tengah } \\
\text { Model } 1 \\
\text { (Akses) }\end{array}$} \\
\hline & $\begin{array}{l}\text { Model } 1 \\
\text { (Akses) }\end{array}$ & $\begin{array}{c}\text { Model } 2 \\
\text { (Sumber) }\end{array}$ & $\begin{array}{c}\text { Model } 1 \\
\text { (Akses) }\end{array}$ & $\begin{array}{c}\text { Model } 2 \\
\text { (Sumber) }\end{array}$ & \\
\hline Konstanta & $0.222 * * *$ & $0.218^{* * *}$ & $0.222 * * *$ & $0.219 * * *$ & $0.302 * * *$ \\
\hline Umur & $-0.000 * *$ & $-0.000 * *$ & $0.001 * * *$ & $0.001 * * *$ & -0.000 \\
\hline D. Jenis kelamin & $0.016^{* * *}$ & $0.016 * * *$ & 0.002 & 0.002 & $0.018^{* *}$ \\
\hline Pendidikan & $-0.002 * * *$ & $-0.002 * * *$ & $-0.003 * * *$ & $-0.003 * * *$ & $-0.004 * * *$ \\
\hline D. Ikut penyuluhan & $-0.009 * * *$ & $-0.009 * * *$ & $-0.025 * * *$ & $-0.025 * * *$ & $-0.048 * * *$ \\
\hline D. Anggota klp. tani & $-0.035 * * *$ & $-0.035 * * *$ & $0.021 * * *$ & $0.021 * * *$ & $0.011 *$ \\
\hline D. Bantuan Usaha & $-0.009 * * *$ & $-0.010 * * *$ & $0.042 * * *$ & $0.042 * * *$ & $0.055^{* * *}$ \\
\hline D. Lahan milik sendiri & $0.046^{* *}$ & $0.046^{* *}$ & $0.008 * *$ & $0.010 * * *$ & $0.034 * * *$ \\
\hline D. Traktor & $-0.053 * * *$ & $-0.053 * * *$ & $-0.090 * * *$ & $-0.092 * * *$ & $-0.059 * * *$ \\
\hline D. Musim hujan & $0.021 * * *$ & $0.021 * * *$ & $0.016^{* * *}$ & $0.015 * * *$ & -0.002 \\
\hline D. Sawah irigasi & $-0.040 * * *$ & $-0.039 * * *$ & $-0.031 * * *$ & $-0.031 * * *$ & $-0.022 * * *$ \\
\hline D. Akses kredit & $-0.024 * * *$ & - & $-0.026 * * *$ & - & -0.002 \\
\hline D. Lembaga formal & - & $-0.025 * * *$ & - & $-0.021 *$ & - \\
\hline D. Lembaga semiformal & - & $-0.010 *$ & - & $-0.038 * *$ & - \\
\hline $\mathrm{R}^{2}$ & 0.23 & 0.23 & 0.25 & 0.25 & 0.09 \\
\hline $\mathrm{N}$ & 3904 & 3904 & 2455 & 2455 & 3768 \\
\hline
\end{tabular}

Elastisitas variabel tingkat pendidikan menunjukkan arah negatif dan signifikan terhadap inefisiensi teknis pada semua provinsi. Rata-rata persentase petani berpendidikan Sekolah Dasar mencapai $50 \%$ dan lulusan SMP/SMA sebesar 20\%, sisanya yang berpendidikan strata-1 keatas dan yang tidak berpendidikan. Hal tersebut menerangkan bahwa semakin tinggi tingkat pendidikan petani semakin efisien usahatani di masing-masing provinsi penelitian. Penelitian dari Kusnadi et al. (2011) juga menyatakan bahwa semakin tinggi tingkat pendidikan petani semakin efisien usahatani padi di Indonesia. Sejalan dengan penelitian dari Achmad et al. (2012), Junaedi et al. (2017), dan Afrin et al. (2017) yang meneliti efisiensi usahatani padi juga menemukan hal yang sama.
Tabel 9 menerangkan bahwa perbedaan inefisiensi teknis antara petani yang mengikuti penyuluhan dengan yang tidak adalah sebesar 0.009 di Jawa Timur. Efektifitas pemberian penyuluhan menunjukkan koefisien negatif dan signifikan terhadap inefisiensi teknis usahatani padi di semua provinsi Pulau Jawa, artinya petani yang mendapat penyuluhan memiliki rata-rata tingkat efisiensi teknis yang lebih tinggi dibanding yang tidak mendapat penyuluhan. Secara umum penyuluhan berhasil mendorong efisiensi teknis usahatani padi sawah, walaupun persentase petani yang ikut penyuluhan berada pada rentang 30-40\%. Senada dengan hasil penelitiaan Achmad et al. (2012), Abdallah (2016), Afrin et al. (2017) dan Junaedi et al. 
(2017) yang meneliti efisiensi usahatani padi sawah.

Perbedaan inefisiensi teknis antara petani yang menjadi anggota kelompok tani dengan yang tidak adalah sebesar - 0.035 di Jawa Timur. Petani yang menjadi anggota kelompok tani di Jawa Timur berpengaruh negatif dan signifikan terhadap inefisiensi teknis didukung oleh mayoritas petani telah bergabung menjadi anggota kelompok tani sebesar 69\%, artinya petani yang menjadi anggota kelompok tani memiliki tingkat efisiensi yang lebih tinggi. Keanggotaan dalam kelompok tani berpengaruh beragam terhadap inefisiensi. Hal ini mengindikasikan bahwa keanggotaan dalam kelompok tani mampu mendorong peningkatan efisiensi teknis usahatani di Jawa Timur sejalan dengan penelitian Achmad et al. (2012), Tinaprilla et al. (2013), Anggraini et al. (2016) dan Junaedi et al. (2017) yang menunjukkan tanda negatif terhadap inefisiensi usahatani padi. Sebaliknya petani yang menjadi anggota kelompok tani di Jawa Barat dan Jawa Tengah berlawanan arah yang artinya keanggotaan kelompok tani dapat menurunkan efisiensi pada usahatani padi, karena persentase petani yang menjadi anggota kelompok tani kecil di Jawa Barat (33\%). Sejalan dengan penelitian Kusnadi et al.(2011), Abdalllah (2016) dan Afrin et al. (2017) menunjukkan variabel anggota kelompok tani berpengaruh positif terhadap inefisiensi usahatani padi.

Bantuan usaha yang diterima petani berpengaruh negatif dan nyata terhadap inefisiensi teknis usahatani padi di Jawa Timur. Perbedaan nilai inefisiensi teknis antara petani yang mendapatkan bantuan usaha dengan yang tidak mendapatkannya adalah sebesar -0.009, artinya petani yang mendapatkan bantuan usaha memiliki rata-rata tingkat efisiensi teknis yang lebih tinggi dibanding yang tidak mendapatkan bantuan. Bantuan usaha yang dimaksud pada adalah bantuan usahatani berupa hibah (gratis) atau subsidi yang berasal dari pemerintah, lembaga non pemerintah ataupun dari perorangan. Bantuan bisa berbentuk benih, pupuk, pestisida, alat/mesin pertanian maupun pembiayaan. Namun di Jawa Barat dan Jawa Tengah ternyata berpengaruh berbeda, pemberian bantuan justru tidak dapat meningkatkan efisiensi teknis yang ditunjukkan dengan koefisien positif dan signifikan di dua provinsi ini, Karena persentase petani yang mendapatkan bantuan usaha cenderung lebih kecil di Jawa Barat (65\%) dibanding petani di Jawa Timur (82\%). Hal ini menjadi pertanda bagi pihak pemberi bantuan untuk mengevaluasi terhadap penyaluran dan kemanfaatan pemberian bantuan bagi usahatani padi sawah. Sejalan dengan Junaedi et al. (2017) yang menemukan bahwa bantuan berpengaruh positif terhadap inefisiensi usahatani padi di Pulau Jawa.

Berdasarkan Tabel 9, perbedaan nilai inefisiensi teknis petani yang memiliki lahan sendiri dibandingkan dengan petani yang menggarap lahan bukan milik sendiri adalah sebesar 0.046 di Jawa Timur. Variabel lahan milik sendiri ini berpengaruh positif dan signifikan terhadap inefisiensi teknis usahatani padi sawah di Pulau Jawa, artinya petani yang menggarap lahan bukan milik sendiri memiliki rata-rata tingkat efisiensi teknis yang lebih tinggi dibanding petani yang memiliki lahan sendiri. Hal ini disebabkan petani cenderung tidak disiplin dalam pengelolaan lahan sehingga perawatan lahan tidak dilakukan secara teratur. Sebaliknya petani yang menyewa lahan lebih mempertahankan kualitas lahan, karena petani memiliki keterbatasan dalam penguasaan lahan garapan. Rata-rata persentase petani yang menggarap lahan milik sendiri/bebas sewa yang besar $(77-87 \%)$. Hasil sejenis ditunjukkan pada penelitian Tinaprilla et al. (2013) yang menganalisis efisiensi teknis di Jawa Barat dan penelitian Junaedi et al. (2017) di Pulau Jawa yang meneliti efisiensi teknis dan faktor-faktor yang memengaruhinya dengan menggunakan model Stochastic Frontier Production Function, menunjukkan bahwa kepemilikan lahan berpengaruh positif dan signifikan terhadap inefisiensi teknis, artinya lahan sewa dianggap lebih produktif dan lebih efisien dibandingkan status lahan milik sendiri.

Perbedaan nilai inefisiensi teknis petani yang mengolah lahan dengan mesin traktor dibandingkan petani yang mengolah lahan secara tradisional (cangkul dan hewan) sebesar - $0.053 \mathrm{di}$ Jawa Timur. Variabel ini berpengaruh negatif dan signifikan terhadap inefisiensi teknis usahatani padi artinya petani yang telah 
menggunakan alat modern dalam mengolah lahan sawah memiliki tingkat rata-rata efisiensi yang lebih tinggi dibandingkan petani yang mengolah lahan dengan bukan traktor. Rata-rata penggunaan traktor di Pulau Jawa telah tinggi (74 - 85\%) sebagaimana ditunjukkan pada Tabel 4.8. Hal ini memang sangat beralasan karena penggunaan traktor bisa menghemat tenaga kerja dan waktu dalam pengolahan lahan, sejalan dengan penelitian Tinaprilla et al. (2013) dan Junaedi et al. (2017).

Nilai inefisiensi teknis petani yang menanam padi pada musim hujan lebih tinggi sebesar 0.021 dari petani yang menanam padi pada musim kemarau di Jawa Timur. Variabel musim hujan ternyata berpengaruh positif dan signifikan di semua provinsi terhadap inefisiensi teknis, artinya petani yang bertani di musim kemarau memiliki rata-rata tingkat efisiensi teknis yang lebih tinggi dibanding petani yang bertani pada musim hujan. Mayoritas petani di Pulau Jawa telah berusahatani pada lahan sawah irigasi dengan persentase di atas $50 \%$, sehingga petani tidak bergantung pada air hujan yang seringkali dapat menyebabkan banjir dan gagal panen. Hasil ini sejalan dengan penelitian Junaedi et al. (2016) yang meneliti efisiensi dan kesenjangan teknologi di Indonesia menemukan bahwa penanaman padi sawah di musim hujan berpengaruh positif terhadap inefisiensi teknis di Pulau Sumatera, Bali dan Pulau lainnya.

Lahan sawah dengan irigasi teknis mempunyai nilai koefisien bertanda negatif dan signifikan terhadap inefisiensi teknis usahatani padi di Pulau Jawa, serta perbedaan nilai inefisiensi teknis antara petani yang menanam padi di sawah irigasi dibanding pada sawah bukan irigasi adalah sebesar -0.04 di Jawa Timur artinya pengairan dengan infrastruktur irigasi telah mendorong menaikkan tingkat rata-rata efisiensi teknis. Penelitian Abdallah (2016) yang meneliti pengaruh kredit dan efisiensi teknis para petani di Ghana menemukan irigasi berpengaruh negatif terhadap usahatani, dan penelitian Tinaprilla et al. (2013) menyatakan bahwa sebagian besar petani yang menggunakan irigasi lebih efisien dari petani yang tidak menggunakan irigasi. Sawah irigasi yang baik akan memasok air dengan berkelanjutan.
Petani yang mengakses kredit di Jawa Timur dan Jawa Barat memiliki rata-rata efisiensi teknis (ET) lebih tinggi dari petani non-kredit sebesar 0.024 (Jawa Timur) dan 0.026 (Jawa Barat), serta berpengaruh signifikan pada taraf $1 \%$. Hal ini disebabkan rata-rata petani yang telah mengakses kredit lebih besar di Jawa Timur (11\%) dan Jawa Barat (10\%) dibanding dengan petani yang mengakses kredit di Jawa Tengah (6\%). Artinya jika petani diberi akses kredit yang lebih luas sehingga memiliki modal yang cukup akan meningkatkan efisiensi teknis usahatani padi.

Petani yang menerima kredit dominan menggarap lahan yang sempit $(0.3-0.5$ ha $)$, mereka akan mampu mengelola sumber daya secara produktif dengan tambahan modal memadai dibanding petani non-kredit (tingkat efisiensi teknis yang lebih rendah). Hasil ini konsisten dengan literatur yang ada (Duy 2015; Abdallah 2016; Afrin et al. 2017; Chandio et al. 2017). Ini menunjukkan bahwa petani yang mengakses kredit lebih efisien karena memiliki lebih banyak fleksibilitas keuangan untuk membeli input pertanian yang diperlukan secara tepat waktu sehingga dapat mengelola sumber daya secara produktif.

Hasil pengolahan data pada Tabel 9 juga menunjukkan rata-rata tingkat efisiensi petani yang mengambil kredit dari lembaga formal dan semiformal lebih tinggi dibanding yang tidak menerima kredit, serta berpengaruh negatif terhadap inefisiensi usahatani padi sawah di Jawa Timur dan Jawa Barat. Lembaga keuangan baik bank maupun non bank, sangat dibutuhkan dalam usahatani. Terlebih lembaga keuangan yang lokasi dekat dengan petani dan kemudahan akses terhadap kredit akan meningkatkan efisiensi usahatani. Penelitian-penelitian yang mendukung tentang peranan lembaga-lembaga dalam meningkatkan efisiensi juga dilakukan oleh Dong dan Featherstone (2006) di China; Ambali (2013) di Nigeria; Duy (2015) di Vietnam, dan Afrin et al. (2017) di Bangladesh.

\section{Pengaruh akses kredit terhadap inefisiensi teknis.}

Petani yang mengambil kredit pada lembaga formal dapat menurunkan nilai inefisiensi dan memiliki nilai efisiensi teknis yang lebih dibandingkan dengan petani non-kredit (asumsi 
variabel lainnya ceteris paribus), sebagaimana yang ditunjukkan pada Tabel 10. Hasil dari pengolahan model 1 ini hanya menampilkan pengaruh akses kredit yang signifikan dari pendugaan parameter fungsi inefisiensi teknis di Jawa Timur dan Jawa Barat, sedangkan rata-rata efisiensi teknis di Jawa Tengah tidak ditampilkan karena hasil pendugaan akses kredit tidak berpengaruh signifikan.

Sebaran rata-rata efisiensi teknis pada Tabel 10 , petani yang tidak mengakses kredit yaitu 0.83 di Jawa Timur dan 0.79 di Jawa Barat. Rata-rata efisiensi ini akan naik ketika petani mengambil kredit. Petani yang mengakses kredit akan meningkatkan efisiensi teknis menjadi 0.85 dan 0.84 untuk masing-masing Jawa Timur dan Jawa
Barat. Hal ini perlu mendapatkan perhatian dikarenakan masih kecilnya persentase petani yang mengakses kredit di Jawa Timur (11\%); Jawa Barat (10\%) dan Jawa Tengah (6\%) yang secara rata-rata akses kredit di Pulau Jawa sebesar $9 \%$. Dengan meningkatnya jumlah petani yang mengakses kredit akan meningkatkan ratarata efisiensi teknis usahatani padi. Temuan ini sejalan dengan penelitian sebelumnya Ambali (2013) di Nigeria; Duy (2015) di Vietnam, dan Afrin et al. (2017) di Bangladesh yang menemukan petani yang menerima kredit memiliki tingkat efisiensi teknis yang lebih tinggi.

Tabel 10. Sebaran Efisiensi Teknis Usahatani Padi Berdasarkan Akses Kredit di Pulau Jawa

\begin{tabular}{|c|c|c|c|c|c|c|c|c|}
\hline \multirow{3}{*}{$\begin{array}{l}\text { Tingkat } \\
\text { Efisiensi }\end{array}$} & \multicolumn{4}{|c|}{ Tidak ada akses } & \multicolumn{4}{|c|}{ Akses kredit } \\
\hline & \multicolumn{2}{|c|}{ Jawa Timur } & \multicolumn{2}{|c|}{ Jawa Barat } & \multicolumn{2}{|c|}{ Jawa Timur } & \multicolumn{2}{|c|}{ Jawa Barat } \\
\hline & $\begin{array}{c}\text { Jumlah } \\
\text { Petani }\end{array}$ & Persen & $\begin{array}{c}\text { Jumlah } \\
\text { Petani }\end{array}$ & Persen & $\begin{array}{c}\text { Jumlah } \\
\text { Petani }\end{array}$ & Persen & $\begin{array}{c}\text { Jumlah } \\
\text { Petani }\end{array}$ & Persen \\
\hline$<0.30$ & - & - & - & - & - & - & - & - \\
\hline $0.30-0.39$ & - & - & - & - & - & - & - & - \\
\hline $0.40-0.49$ & - & - & 17 & 0.77 & - & - & - & - \\
\hline $0.50-0.59$ & 63 & 1.80 & 132 & 5.99 & 2 & 0.49 & 3 & 1.19 \\
\hline $0.60-0.69$ & 276 & 7.90 & 272 & 12.35 & 12 & 2.92 & 4 & 1.59 \\
\hline $0.70-0.79$ & 657 & 18.81 & 558 & 25.33 & 47 & 11.44 & 40 & 15.87 \\
\hline$>0.80$ & 2497 & 71.49 & 1223 & 55.56 & 350 & 85.16 & 205 & 81.35 \\
\hline Jumlah & 3493 & 100.00 & 2203 & 100.00 & 411 & 100.00 & 252 & 100.00 \\
\hline Rata-rata & \multicolumn{2}{|c|}{0.83} & \multicolumn{2}{|c|}{0.79} & \multicolumn{2}{|c|}{$0.85^{*}$} & \multicolumn{2}{|c|}{$0.84 *$} \\
\hline Minimum & \multicolumn{2}{|c|}{0.54} & \multicolumn{2}{|c|}{0.43} & \multicolumn{2}{|c|}{0.59} & \multicolumn{2}{|c|}{0.55} \\
\hline Maximum & \multicolumn{2}{|c|}{0.95} & \multicolumn{2}{|c|}{0.94} & \multicolumn{2}{|c|}{0.94} & \multicolumn{2}{|c|}{0.94} \\
\hline
\end{tabular}

Ket: *= Uji independen $\mathrm{t}$ test, $\mathrm{P}$-value signifikan pada $\alpha=5 \%$

Berdasarkan hasil uji independen $\mathrm{t}$ test (lampiran 17), diperoleh nilai t hitung di Jawa Timur sebesar 9.45 dan Jawa Barat sebesar 12.99 dengan p-value lebih kecil dari batas kritis $\alpha=$ 0.05 sehingga jawaban adalah menerima $\mathrm{H} 1$ atau berarti terdapat perbedaan rata-rata yang signifikan antara efisiensi teknis usahatani padi yang menerima kredit daripada usahatani padi non-kredit.

\section{SIMPULAN DAN SARAN}

\section{Simpulan}

Determinan faktor-faktor input yang berpengaruh positif dan signifikan terhadap produksi padi di Jawa Timur dan Jawa Barat adalah lahan, pupuk urea/ZA, pupuk TSP/SP36, pupuk KCL, pestisida sementara di Jawa Tengah adalah luas lahan, benih dan pupuk TSP/SP36. Penggunaan tenaga kerja ternyata berpengaruh negatif di semua provinsi penelitian.

Usahatani padi di Pulau Jawa telah efisien secara teknis, rata-rata efisiensi teknis (ET) tinggi di Jawa Timur (0.84), Jawa Barat (0.79) dan Jawa Tengah (0.71). Sementara secara alokatif dan ekonomi belum efisien, dengan rata-rata efisiensi alokatif (EA) rendah di Jawa Timur (0.36), Jawa Barat (0.47) dan Jawa Tengah (0.48). Hal yang sama menunjukkan rata-rata 
efisiensi ekonomi (EE) rendah di Jawa Timur (0.30), Jawa Barat (0.36) dan Jawa Tengah (0.32). Hal ini disebabkan petani belum mengelola usahataninya dengan meminimalkan biaya.

Akses kredit yang diterima petani dari lembaga formal dan lembaga semiformal berpengaruh negatif dan nyata terhadap inefisiensi teknis usahatani padi di Jawa Timur dan Jawa Barat. Petani yang mengakses kredit memiliki rata-rata efisiensi teknis lebih tinggi daripada petani non-kredit sebesar 0.024 di Jawa Timur dan 0.026 di Jawa Barat. Petani yang mengambil kredit di lembaga formal memiliki rata-rata efisiensi teknis yang lebih tinggi daripada petani non-kredit sebesar 0.025 di Jawa Timur dan 0.021 di Jawa Barat. Sementara petani yang mengambil kredit di lembaga semiformal memiliki rata-rata efisiensi teknis yang lebih tinggi daripada petani non-kredit sebesar $0.010 \mathrm{di}$ Jawa Timur dan 0.038 di Jawa Barat.

\section{Saran}

Pemerintah sebaiknya berperan dalam penguatan kebijakan terkait perlindungan hargaharga input agar lebih terjangkau oleh petani dan pengamanan harga gabah agar saat panen dan menjual gabahnya, petani tidak merugi dan mendapat insentif untuk tetap mau bertani. Akses kredit petani masih rendah (9\%), sehingga kebijakan dari pemerintah dan Bank Indonesia untuk menciptakan keuangan yang iklusif khususnya pada daerah pedesaan seperti program laku pandai dapat ditingkatkan.

Penguatan lembaga keuangan semiformal di pedesaan perlu mendapat dukungan, seperti koperasi simpan pinjam, baitul maal wa tamwil dll, karena lokasinya lebih dekat dengan petani. Saran untuk penelitian pengaruh kredit terhadap efisiensi berikutnya agar memasukkan variabel jumlah kredit, tingkat suku bunga dan sistem pengembalian kredit.

\section{DAFTAR PUSTAKA}

Achmad M. 2012. Pengaruh Aksesibilitas Penyuluhan dan Kredit terhadap Efisiensi Usahatani Padi di Jawa. Jurnal Trikonomika. 11(1):69-80,
Afrin S, Haider MZ, Islam MS. 2017. Impact of Financial Inclusion on Technical Efficiency of Paddy Farmers in Bangladesh. Agricultural Finance Review. 77(4):484-505.

Abdallah AH. 2016. Agricultural Credit and Technical Efficiency in Ghana: Is There a Nexus?. Agricultural Finance Review. 76(2):309-324.

Aigner, DJ, Lovell CAK, Schmidt P. 1977. Formulation and Estimation of Stochastic Frontier Production Function Model. Journal of Econometrics, 6(1):21-37

Ambali OI. 2013. Microcredit and Technical Efficiency of Rural Farm Households in Egba Division of Ogun State Nigeria. Journal of Agriculture and Sustainability. 2(2).

Anggraini N, Harianto, Anggraeni L. 2016. Efisiensi Teknis, Alokatif dan Ekonomi pada Usahatani Ubikayu di Kabupaten Lampung Tengah, Provinsi Lampung. Jurnal Agribisnis Indonesia. 4(1):43-56.

Ashari. 2009. Optimalisasi Kebijakan Kredit Program Sektor Pertanian di Indonesia. Analisis Kebijakan Pertanian. 7(1):2142.

[BI] Bank Indonesia. 2016. Laporan "Pilot Project Skema Pembiayaan Pertanian melalui Penerapan Konsep Pembiayaan Rantai Nilai". Jakarta (ID): [DPU] Bank Indonesia.

[BPS] Badan Pusat Statistik. 2011. Struktur Ongkos Usaha Tani Tanaman Pangan 2011. Jakarta (ID). Badan Pusat Statistik.

[BPS] Badan Pusat Statistik. 2013. Proyeksi Penduduk Indonesia 201p-2035. Jakarta (ID): BPS

[BPS] Badan Pusat Statistik. 2019a. Produksi Padi di Indonesia menurut Provinsi Tahun 1993 - 2015 dan Tahun 2018. Jakarta (ID): BPS.

[BPS] Badan Pusat Statistik. 2019b. Pendapatan Nasional Indonesia 2014-2018. Jakarta (ID): BPS.

[BPTP] Balai Pengkajian Teknologi Pertanian Sulawesi Selatan. 2016. Teknik Perbanyakan Benih Padi Bermutu. Makassar (ID): BPTP. 
Boris E, Ant BU, Pinheiro OE. 1997. Technical, Economic, and Allocative Efficiency in Peasant Farming: Evidence from the Dominican Republik. The Developing Economies. 35(1):48-67

Chandio AA, Jiang Y, Gessess AT, Dunya R. 2017. The Nexus of Agricultural Credit, Farm Size and Technical Efficiency in Sindh, Pakistan: A Stochastic Production Frontier Approach. Journal of the Saudi Society of Agricultural Sciences. 18(3):348-354.

Coelli TJ, Rao DS, O'Donnell CJ, Battese GE. 2005. An Introduction to Efficiency and Productivity Analysis Second Edition. New York (US): Springer Science.

Demirgüç-Kunt A, Beck TH, Honohan, P. 2008. Finance for all? Policies and Pitfalls in Expanding Access. Washington DC (US): World Bank.

Duy VQ. 2015. Access to Credit and Rice Production Efficiency of Rural Households in the Mekong Delta. Sociology and Anthropology. 3(9):425433.

Dong F, Featherstone AM. 2006. Technical and Scale Efficiencies for Chinese Rural Credit Cooperatives: A Bootstrapping Approach in Data Envelopment Analysis. Journal of Chinese Economic and Business Studies. 4(1):57-75.

Fazri M, Siregar H, Nuryartono N. 2017. Efisiensi Teknis, Pertumbuhan Teknologi dan Total Faktor Produktivitas pada Industri Menengah dan Besar di Indonesia. Jurnal Ekonomi dan Kebijakan Pembangunan. 6(1):1-20

Farrell MJ. 1957. The measurement of productive efficiency. Journal of the Royal Statistical Society. Series A (General). 120(3):253-290.

Fadwiwati AY. 2013. Pengaruh penggunaan varietas unggul terhadap efisiensi, pendapatan, dan distribusi pendapatan petani jagung di Provinsi Gorontalo. [Disertasi]. Bogor (ID). Institut Pertanian Bogor.

Junaedi M, Daryanto HK, Sinaga BM, Hartoyo S. 2016. Technical Efficiency And The Technology Gap In Wetland Rice
Farming in Indonesia: A Metafrontier Analysis. International Journal of Food and Agricultural Economics. 4(2):39-50.

Junaedi M, Daryanto HKS, Sinaga BM, Hartoyo S. 2017. Efisiensi dan Kesenjangan Teknologi Usahatani Padi Sawah di Pulau Jawa. Jurnal Aplikasi Statistika \& Komputasi Statistik. 8(2):1-19.

Kusnadi N, Tinaprilla N, Susilowati SH, Purwoto

A. 2011. Analisis Efisiensi Usahatani Padi di beberapa Sentra Produksi Padi di Indonesia. Jurnal Agro Ekonomi. 29(1):25-48.

Koopmans TC. 1951. Activity Analysis of Production and Allocation. Di dalam: Alchian A, Dantzig GB, GeorgescuRoegen N, Samuelson PA, Tucker AW,editor. Cowles Commission for Research in Economics Monograph No.13; 1951; New York, United State of America. New York (US): The University of Chicago. Page 33-97.

Machmuddin N. 2016. Analisis Efisiensi Ekonomi Usahatani Padi Organik dan Konvensional [tesis]. Bogor (ID): Institut Pertanian Bogor

Nicholson W. 2004. Mikroekonomi Intermediate \& Aplikasinya Edisi 8. Jakarta (ID): Erlangga

Nuryartono N. 2007. Credit Rationing of Farm Households and Agricultural Production: Empirical Evidence in The Rural Areas of Central Sulawesi, Indonesia. Jurnal Manajemen Agribisnis. 4(1):15-21.

[OJK] Otoritas Jasa Keuangan. 2018. Laporan Profil Industri Perbankan Triwulan IV 2017. Jakarta (ID): OJK.

Quartey P, Turkson E, Abor JY, Iddrisu AM. 2017. Financing the growth of SMEs in Africa: What are the contraints to SME financing within ECOWAS. Review of Development Finance. 7(1):18-28.

Qureshi SK, Shah AH. 1992. A Critical Review of Rural Credit Policy in Pakistan. The Pakistan Development Review. 31(4):781-801.

Sarma M, Pais J. 2011. Financial Inclusion and Development. Journal of International Development. 23:613-628. 
Satoto, Suprihatno B. 2008. Pengembangan Padi Hibrida di Indonesia. Iptek Tanaman Pangan. 3(1):27-40

Swamy V. 2014. Financial Inclusion Gender Dimension and Economic Impact on Poor Households. World Development. 56:1-15.

Tenaw S, Islam KZ. 2009. Rural Financial Services and Effects of Microfinance on Agricultural Productivity and on Poverty (Discussion Papers series). Helsinki (FI):
University of Helsinki Department of Economics and Management.

Tinaprilla N. 2013. Analisis Efisiensi Teknis Usahatani Padi di Jawa Barat Indonesia. Jurnal Agribisnis. 7(1):15-34

Wati DR, Nuryartono N, Anggraeni L. 2014. Akses dan Dampak Kredit Mikro terhadap Produksi Padi Organik di Kabupaten Bogor. Jurnal Ekonomi dan Kebijakan Pembangunan. 3(2):75-94. 